This document is confidential and is proprietary to the American Chemical Society and its authors. Do not copy or disclose without written permission. If you have received this item in error, notify the sender and delete all copies.

\title{
Betulonic acid derivatives interfering with human coronavirus 229 E replication via the nsp15 endoribonuclease
}

\begin{tabular}{|c|c|}
\hline Journal: & Journal of Medicinal Chemistry \\
\hline Manuscript ID & jm-2020-02124d.R2 \\
\hline Manuscript Type: & Article \\
\hline $\begin{array}{r}\text { Date Submitted by the } \\
\text { Author: }\end{array}$ & $\mathrm{n} / \mathrm{a}$ \\
\hline Complete List of Authors: & $\begin{array}{l}\text { Stevaert, Annelies; KU Leuven, Rega Institute } \\
\text { Krasniqi, Besir; KU Leuven, Department of Chemistry } \\
\text { Van Loy, Benjamin; KU Leuven, Rega Institute } \\
\text { Nguyen, Tien; KU Leuven, Department of Chemistry } \\
\text { Thomas, Joice; Arcus Biosciences Inc, The Bridge@USC and Loker } \\
\text { Hydrocarbon Research Institute } \\
\text { Vandeput, Julie; KU Leuven, Rega Institute } \\
\text { Jochmans, Dirk; KU Leuven, Rega Institute } \\
\text { Thiel, Volker; Institute of Virology and Immunology; University of Bern, } \\
\text { Department of Infectious Diseases and Pathobiology, Vetsuisse Faculty } \\
\text { Dijkman, Ronald; Institute of Virology and Immunology; University of } \\
\text { Bern, Department of Infectious Diseases and Pathobiology, Vetsuisse } \\
\text { Faculty; University of Bern, Institute for Infectious Diseases (IFIK) } \\
\text { Dehaen, Wim; KU Leuven, Department of Chemistry } \\
\text { voet, arnout; KU Leuven, Department of Chemistry } \\
\text { Naesens, Lieve; KU Leuven, Rega Institute }\end{array}$ \\
\hline
\end{tabular}

\section{SCHOLARONE"N Manuscripts}




\title{
Betulonic acid derivatives interfering with human coronavirus $229 \mathrm{E}$ replication via the nsp15 endoribonuclease
}

\author{
Annelies Stevaert ${ }^{1 \#}$, Besir Krasniqi ${ }^{2 \# *}$, Benjamin Van Loy ${ }^{1}$, Tien Nguyen $^{2,3}$, Joice Thomas ${ }^{2}$, \\ Julie Vandeput ${ }^{1}$, Dirk Jochmans ${ }^{1}$, Volker Thiel ${ }^{4,5}$, Ronald Dijkman, ${ }^{4,6}$, Wim Dehaen ${ }^{2}$, Arnout \\ Voet $^{3}$, Lieve Naesens ${ }^{1 *}$
}

${ }^{1}$ Laboratory of Virology and Chemotherapy, Rega Institute, KU Leuven, 3000 Leuven, Belgium. ${ }^{2}$ Molecular Design and Synthesis, Department of Chemistry, KU Leuven, 3001 Leuven, Belgium.

${ }^{3}$ Biochemistry, Molecular and Structural Biology, Department of Chemistry, KU Leuven, 3001 Leuven, Belgium.

${ }^{4}$ Institute of Virology and Immunology (IVI), 3012 Bern and 3147 Mittelhäusern, Switzerland. ${ }^{5}$ Department of Infectious Diseases and Pathobiology, Vetsuisse Faculty, University of Bern, 3012 Bern, Switzerland.

${ }^{6}$ Institute for Infectious Diseases (IFIK), University of Bern, 3012 Bern, Switzerland.

\#These authors contributed equally.

*Corresponding author for biology. Email: lieve.naesens@kuleuven.be. Phone: $(+32) 16322098$.

*Corresponding author for chemistry. Email: besir.krasniqi@kuleuven.be. Phone: $(+32) 496798402$

Keywords: coronavirus, antiviral, nsp15, endoribonuclease, betulonic acid 


\begin{abstract}
To develop antiviral therapeutics against human coronavirus (HCoV) infections, suitable coronavirus drug targets and corresponding lead molecules must be urgently identified. Here we describe the discovery of a class of HCoV inhibitors acting on nsp15, a hexameric protein component of the viral replication-transcription complexes, endowed with immune evasionassociated endoribonuclease activity. SAR exploration of these 1,2,3-triazolo fused betulonic acid derivatives yielded lead molecule $5 \mathrm{~h}$ as a strong inhibitor (antiviral $\mathrm{EC}_{50}: 0.6 \mu \mathrm{M}$ ) of $\mathrm{HCoV}$ 229E replication. An nsp15 endoribonuclease active site mutant virus was markedly less sensitive to $\mathbf{5 h}$, and selected resistance to the compound mapped to mutations in the $\mathrm{N}$ terminal part of HCoV-229E nsp15, at an interface between two nsp15 monomers. The biological findings were substantiated by the nsp15 binding mode for $\mathbf{5 h}$, predicted by docking. Hence, besides delivering a distinct class of inhibitors, our study revealed a druggable pocket in the nsp15 hexamer with relevance for anti-coronavirus drug development.
\end{abstract}




\section{INTRODUCTION}

Four human CoVs (i.e. HCoV-229E, -HKU1, -NL63, and -OC43) are endemic in the population and account each year for 15 to $30 \%$ of common colds. ${ }^{1}$ These can evolve into life-threatening lower respiratory tract infections in elderly, children and persons at risk. ${ }^{2,3}$ Besides, the current SARS-CoV-2 pandemic is causing a major crisis in terms of human health and socio-economic losses. Within a period of $\sim 20$ years, SARS-CoV-2 is the third zoonotic coronavirus (CoV) to enter the human species, coming after SARS (Severe Acute Respiratory Syndrome) and MERS (Middle East Respiratory Syndrome). ${ }^{4}$ Finally, the Coronaviridae family contains several species causing serious disease in pets and livestock. ${ }^{5}$

Somewhat similar to the respiratory illness caused by endemic HCoVs, SARS-CoV-2 produces no or relatively mild disease in most young persons. ${ }^{6}$ In contrast, in individuals with comorbidities or higher age, the SARS-CoV-2 replication phase is typically followed by a second phase that is characterized by hyperinflammation, acute respiratory distress and multiorgan failure. ${ }^{7}$ Hence, management of COVID-19 most likely requires antiviral drugs to suppress initial virus replication, plus anti-inflammatory medication, like corticosteroids, to treat severe cases. ${ }^{8}$ Several CoV proteins may be suitable drug targets, ${ }^{9}$ but, at the moment, only two drug classes have reached formal approval by the FDA, i.e. anti-spike antibodies ${ }^{10}$ and the nucleotide analogue remdesivir, which inhibits the viral polymerase. Based on its interaction with the highly conserved polymerase catalytic site, remdesivir exhibits pancoronavirus activity covering also HCoV-229E. ${ }^{11-14}$ This broad CoV coverage also applies to the clinical candidate GC376, a catalytic site inhibitor of the CoV main protease (Mpro.$^{15-17}$ Though less explored, the CoV nsp15 endoribonuclease (EndoU) is a highly attractive drug target, since it has no cellular counterpart, its catalytic site is conserved among CoVs, and it is amenable to structure-based design based on available protein structures. ${ }^{18-22} \mathrm{Nsp} 15$ is one of the non-structural protein (nsp) components of the replication-transcription complexes (RTCs), the site where CoV RNA synthesis occurs. ${ }^{5,23,24}$ Although the functions of nsp15 are 
not entirely understood, its EndoU function is known to regulate viral RNA synthesis, limit the recognition of viral dsRNA by cellular sensors and prevent the dsRNA-activated antiviral host cell response. ${ }^{25-29}$ The interferon type I evading activity of nsp15 is well elaborated for mouse coronavirus MHV-A5925 and HCoV-229E ${ }^{26}$ and was recently also demonstrated for SARSCoV-2. ${ }^{30}$ The concept to inhibit nsp15 is thus unique, since it combines a direct antiviral effect with the potential to revert viral evasion from host cell immunity.

We here report identification of a class of HCoV-229E nsp15 inhibitors with 1,2,3-triazolo fused betulonic acid structure. We describe their synthesis, structure-activity relationship and the mechanistic findings, in particular resistance data, that corroborate nsp15 as the antiviral target for HCoV-229E. These biological data accord with the binding model that we obtained by compound docking in the hexameric nsp15 protein structure. The model also explains why the current lead is active against $\mathrm{HCoV}-229 \mathrm{E}$, but not other coronaviruses like SARS-CoV-2. In short, our study validates the nsp15 protein, and particularly the interface where the lead compound binds, as a druggable and pertinent target for developing CoV inhibitors. 


\section{RESULTS AND DISCUSSION}

\section{Compound synthesis and structure-activity relationship}

Since the 1,2,3-triazole moiety has the unique property to both accept and donate hydrogen bonds, introducing this moiety can increase the potency of pharmacologically active molecules $^{31-34}$ We decided to fuse this group to betulonic acid, a pentacyclic triterpenoid compound that was the starting point for a wide variety of agents with potential pharmacological use. ${ }^{35-37}$ For instance, the betulinic acid core is present in bevirimat, an HIV maturation inhibitor that has undergone Phase 2 clinical evaluation. ${ }^{38,} 39$ The 1,2,3-triazolo fused betulonic acid derivatives (Scheme 1) were synthesized by our recently developed and convenient "triazolization" method to prepare 1,2,3-triazoles from primary amines and ketones. ${ }^{40-42}$ First, Jones oxidation was performed to convert betulin 1 into betulonic acid 2 (Scheme 1). ${ }^{43}$ Betulin 1, a natural compound isolated from the bark of Betula species, is commercially available. ${ }^{44-46} \mathrm{Next}$, the triazolization method was applied to betulonic acid $\mathbf{2}$ as the ketone source, using primary amines 3 and 4-nitrophenyl azide 4, and the previously reported reaction conditions. ${ }^{40}$. This yielded a series of sixteen 1,2,3-triazolo fused betulonic acids 5 , most of which were isolated at high yield ( $80 \%$; Table 1$)$. Diverse primary amines 3 were attached to the 1,2,3-triazole ring to introduce a variety of aromatic or aliphatic moieties.

Scheme 1. Synthesis of fused 1,2,3-triazole betulonic acid derivatives starting from betulin. 


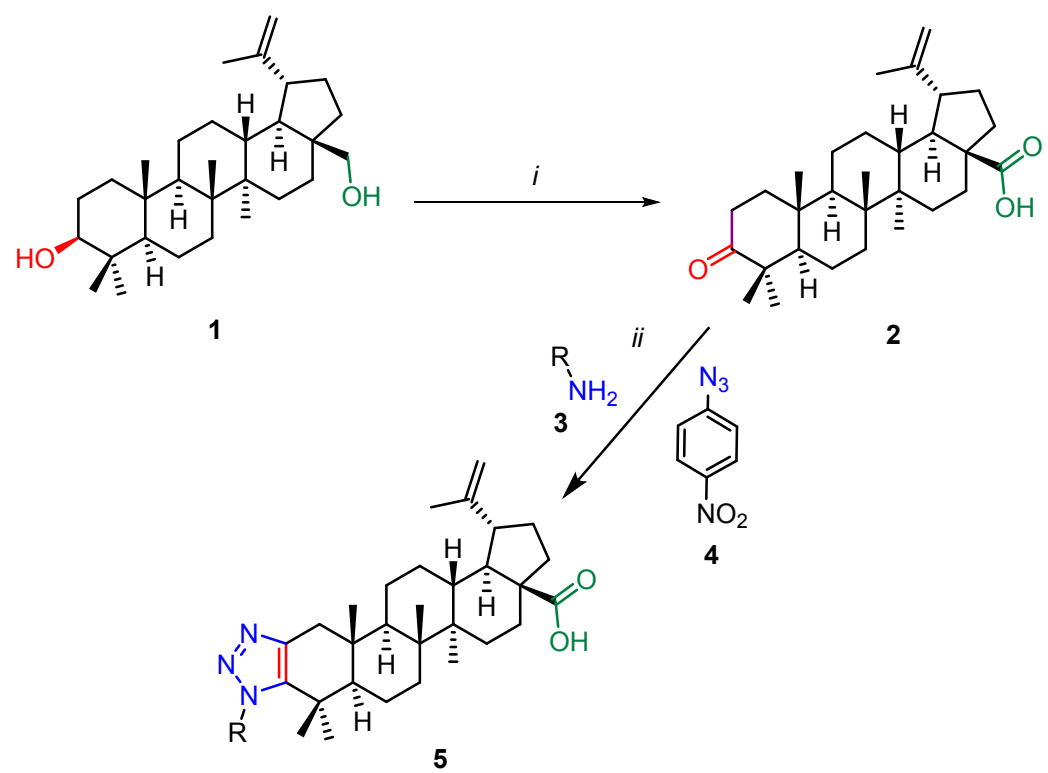

Reagents and conditions: (i) $\mathrm{Na}_{2} \mathrm{Cr}_{2} \mathrm{O}_{7}, \mathrm{H}_{2} \mathrm{SO}_{4}$, acetone, $\mathrm{H}_{2} \mathrm{O}, 0{ }^{\circ} \mathrm{C}$ to r.t., $1 \mathrm{~h}$; (ii) betulonic acid 2 (1.0 equiv.), primary amine 3 (1.4 equiv.), 4-nitrophenyl azide 4 (1.0 equiv.), toluene $(0.4 \mathrm{~mL}), 100{ }^{\circ} \mathrm{C}, 4 \AA$ MS, $24 \mathrm{~h}$.

Table 1. Anti-CoV activity and selectivity in human HEL a cells infected with HCoV-229E.

\begin{tabular}{|c|c|c|c|c|c|c|}
\hline \multirow[t]{2}{*}{ Code } & \multirow[t]{2}{*}{$\mathrm{R}$} & \multirow[t]{2}{*}{$\begin{array}{c}\text { Yield } \\
\%^{b}\end{array}$} & \multicolumn{2}{|c|}{$\begin{array}{c}\text { Antiviral activityc } \\
(\mu \mathrm{M})\end{array}$} & \multirow{2}{*}{$\begin{array}{l}\text { Cytotoxicity }^{d} \\
\qquad(\mu \mathrm{M}) \\
\mathrm{CC}_{50}\end{array}$} & \multirow[t]{2}{*}{$\mathrm{Sl}$} \\
\hline & & & $\mathrm{EC}_{50}$ (MTS) & $\mathrm{EC}_{50}$ (CPE) & & \\
\hline K22 & & & $4.4 \pm 0.9$ & $3.3 \pm 1.0$ & $26 \pm 5$ & 6 \\
\hline GS-441524 & & & $2.3 \pm 0.3$ & $3.2 \pm 0.3$ & $>100$ & $>44$ \\
\hline $5 a$ & & 84 & $1.9 \pm 0.5$ & $1.6 \pm 0.5$ & $10 \pm 2$ & 5 \\
\hline $5 b$ & & 92 & $2.4 \pm 0.8$ & $1.6 \pm 0.5$ & $17 \pm 6$ & 7 \\
\hline $5 c$ & & 78 & $2.5 \pm 0.7$ & $2.4 \pm 0.7$ & $17 \pm 4$ & 7 \\
\hline $5 d$ & & 90 & $6.2 \pm 2.4$ & $3.3 \pm 0.9$ & $57 \pm 16$ & 9 \\
\hline
\end{tabular}




\begin{tabular}{|c|c|c|c|c|c|}
\hline $5 e$ & 85 & $2.2 \pm 0.8$ & $0.88 \pm 0.04$ & $9.3 \pm 3.1$ & 4 \\
\hline $5 f$ & 80 & $4.8 \pm 0.7$ & $3.6 \pm 0.5$ & $\geq 47$ & $\geq 10$ \\
\hline $5 g$ & 80 & $0.54 \pm 0.02$ & $0.51 \pm 0.10$ & $16 \pm 2$ & 31 \\
\hline $5 \mathrm{~h}$ & 84 & $0.65 \pm 0.08$ & $0.60 \pm 0.18$ & $49 \pm 2$ & 76 \\
\hline $5 \mathbf{i}$ & 82 & $13 \pm 3$ & $14 \pm 5$ & $\geq 79$ & $\geq 6$ \\
\hline $5 j$ & 78 & $1.9 \pm 0.4$ & $1.5 \pm 0.7$ & $15 \pm 1$ & 8 \\
\hline $5 \mathbf{k}$ & 53 & $2.6 \pm 0.2$ & $1.1 \pm 0.2$ & $20 \pm 6$ & 8 \\
\hline 51 & 84 & $0.56 \pm 0.07$ & $0.24 \pm 0.03$ & $3.2 \pm 0.2$ & 6 \\
\hline $5 m$ & 88 & $0.88 \pm 0.36$ & $0.30 \pm 0.05$ & $8.9 \pm 4.5$ & 10 \\
\hline $5 n$ & 73 & $0.092 \pm 0.030$ & $0.10 \pm 0.03$ & $2.4 \pm 0.1$ & 27 \\
\hline 50 & 62 & $3.3 \pm 0.4$ & $2.2 \pm 0.8$ & $4.9 \pm 1.7$ & 1.5 \\
\hline $5 p$ & 57 & $2.0 \pm 0.4$ & $1.1 \pm 0.3$ & $16 \pm 2$ & 8 \\
\hline 1 & & $>100$ & $11 \pm 5$ & $7.6 \pm 1.0$ & - \\
\hline 2 & & $>100$ & $>100$ & $>100$ & - \\
\hline
\end{tabular}

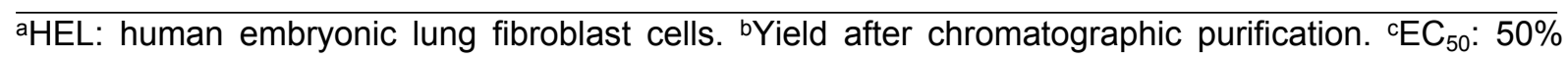
effective concentration, i.e. compound concentration producing $50 \%$ protection against viral cytopathic effect (CPE), as assessed by MTS cell viability assay or microscopic scoring of the CPE. ${ }^{d} C_{50}: 50 \%$ cytotoxic concentration determined by MTS cell viability assay. eSelectivity index or ratio of $\mathrm{CC}_{50}$ to $\mathrm{EC}_{50}$, both determined by MTS assay. Values are the mean \pm SEM $(N=3)$.

To establish the antiviral activity of the synthesized compounds, the molecules were submitted to cell-based assays with a broad range of DNA- and RNA-viruses. This phenotypic screening 
indicated strong and selective activity in human embryonic lung (HEL) fibroblast cells infected with HCoV-229E. We used a viral cytopathic effect (CPE) reduction assay, in which protection against $\mathrm{CPE}$ (expressed as the antiviral $\mathrm{EC}_{50}$ value) was monitored by the MTS cell viability assay and verified by microscopy. The MTS assay was also used to quantify compound cytotoxicity (expressed as the $\mathrm{CC}_{50}$ value) in mock-infected cells. Whereas the starting compounds betulin 1 and betulonic acid 2 were virtually inactive, almost all 1,2,3-triazolo fused betulonic acid derivatives proved to be highly effective CoV inhibitors (Table 1). Several compounds in the series had $\mathrm{EC}_{50}$ values below $1 \mu \mathrm{M}$, which makes them superior to two known CoV inhibitors which we used as reference compounds, i.e. K22 ${ }^{47}$ and GS-441524, the nucleoside form of remdesivir. ${ }^{13}$ Three analogues stood out for having superior selectivity, i.e., $\mathbf{5 g}, \mathbf{5 h}$ and $\mathbf{5 n}$, having a selectivity index (ratio of $\mathrm{CC}_{50}$ to $\mathrm{EC}_{50}$ ) of 31,76 and 27 , respectively. On the other hand, far lower activity was noted for $5 i\left(E_{50}\right.$ value: $\left.13 \mu \mathrm{M}\right)$, which bears a nonaromatic cyclohexanemethyl substituent. Apparently, introducing this bulky group caused a considerable reduction in antiviral activity and selectivity. The capacity of $\mathbf{5 h}$ to fully suppress HCoV-229E replication at non-toxic concentrations is evident from the microscopic images in Figure $1 \mathrm{~A}$ and the dose-response curves in Figure 1B. Also, $5 \mathrm{~h}$ fully prevented the formation of dsRNA intermediates of CoV RNA synthesis, as demonstrated by immunofluorescence staining of dsRNA in HCoV-229E-infected human bronchial epithelial 16HBE cells (Figure 1C). 


\section{A}

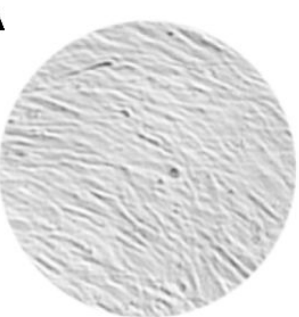

uninfected

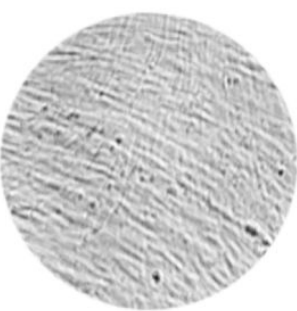

$6.3 \mu \mathrm{M} 5 \mathrm{~h}$

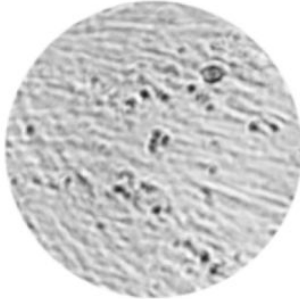

$1.6 \mu \mathrm{M} 5 \mathrm{~h}$

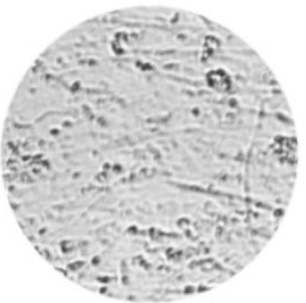

$0.39 \mu \mathrm{M} 5 \mathrm{~h}$

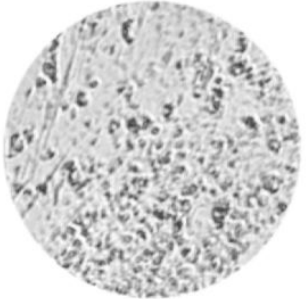

virus control
B

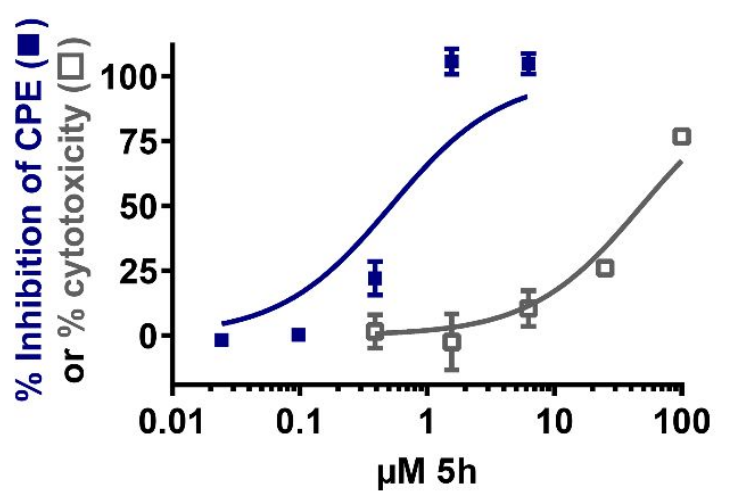

C

\section{\begin{tabular}{|l|l|l|}
\hline virus control & 5h & GS-441524 \\
\hline
\end{tabular}}
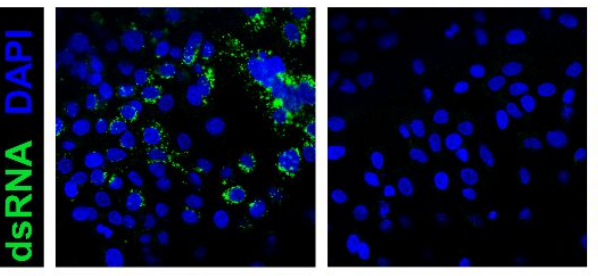

Figure 1. Activity of $5 \mathrm{~h}$ against $\mathrm{HCoV}-229 \mathrm{E}$. (A) Representative microscopic images showing protection against virus-induced cytopathic effect (CPE) in human embryonic lung (HEL) cells. (B) Dose-response curves for inhibition of virus-induced CPE ( $\mathbf{\square})$ and for cytotoxicity $(\square)$ in HEL cells, both determined by MTS cell viability assay. Data points are the mean \pm SEM $(N=3)$. (C) Immunofluorescence detection of viral dsRNA in HCoV-229E-infected human bronchial epithelial 16HBE cells at $24 \mathrm{~h}$ post-infection (p.i.). In green: dsRNA and in blue: nuclear DAPI staining. Compounds: $12 \mu \mathrm{M}$ 5h or $12 \mu \mathrm{M}$ GS-441524. Scale bar: $50 \mu \mathrm{m}$.

To conduct a SAR exploration around lead compound 5 h (Scheme 2 and Table 2), we first investigated the contribution of the $\alpha$-methyl-phenylene moiety. Compound $\mathbf{5 q}$, in which this entire moiety is missing, had $\sim 6$-fold lower antiviral activity than $\mathbf{5 h}$. When only the a-methyl was missing (5r), the activity was not affected. Compound $\mathbf{5 s}$, which is the epimer at the $1,2,3-$ triazole substituent, displayed almost the same $\mathrm{EC}_{50}$ value as $\mathbf{5 h}$, indicating that isomerism does not alter the activity. Cytotoxicity was however slightly decreased, resulting in an even better selectivity index $(\geq 90)$ than that of $\mathbf{5 h}$. In order to elucidate the role of the isopropenyl side chain, we reduced this moiety by hydrogenation, yielding compound $\mathbf{5 t}$ which was 10 - to 
20-fold less active. Replacement of the carboxylic acid by a methyl group (5u) proved deleterious.

Scheme 2. SAR study around compound $5 \mathrm{~h}$.

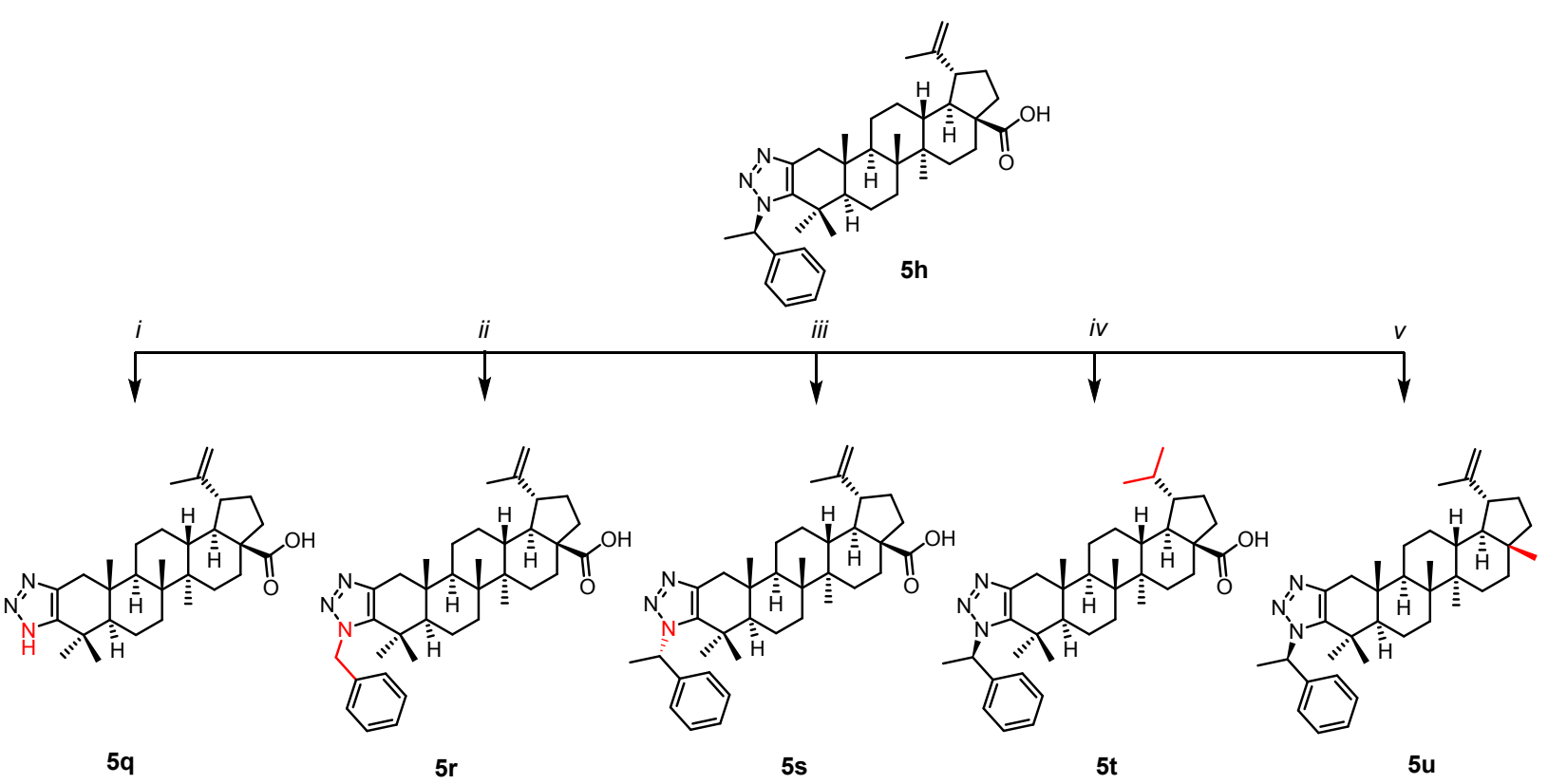

Reagents and conditions: (i) betulonic acid, $\mathrm{NH}_{4} \mathrm{OAc}$, 4-nitrophenyl azide, DMF, $80{ }^{\circ} \mathrm{C}, 18 \mathrm{~h}, 4 \AA \mathrm{MS}$, isolated yield $86 \%$; (ii) betulonic acid, benzyl amine, 4-nitrophenyl azide, toluene, $100{ }^{\circ} \mathrm{C}, 18 \mathrm{~h}, 4 \AA \mathrm{MS}$, isolated yield $92 \%$; (iii) betulonic acid, (R)-(+)-a-methylbenzylamine, 4-nitrophenyl azide, toluene, 100 ${ }^{\circ} \mathrm{C}, 18 \mathrm{~h}, 4 \AA \mathrm{MS}$, isolated yield $69 \%$; (iv) dihydrobetulonic acid, (S)-(-)-a-methylbenzylamine, 4nitrophenyl azide, toluene, $100{ }^{\circ} \mathrm{C}, 18 \mathrm{~h}, 4 \AA \mathrm{MS}$, isolated yield $90 \%$; (v) lupenone, (S)-(-)-amethylbenzylamine, 4-nitrophenyl azide, toluene, $100^{\circ} \mathrm{C}, 18 \mathrm{~h}, 4 \AA \mathrm{MS}$, isolated yield $83 \%$. 
Table 2. Activity of $\mathbf{5 h}$ analogues in human HEL a cells infected with HCoV-229E.

\begin{tabular}{ccccc}
\hline Code & \multicolumn{2}{c}{ Antiviral activity $(\mu \mathrm{M})$} & $\begin{array}{c}\text { Cytotoxicity } \\
(\mu \mathrm{M})\end{array}$ & $\mathrm{Sl}^{\mathrm{d}}$ \\
& $\mathrm{EC}_{50}(\mathrm{MTS})$ & $\mathrm{EC}_{50}(\mathrm{CPE})$ & $\mathrm{CC}_{50}$ & \\
\hline $\mathbf{5 q}$ & $4.3 \pm 0.6$ & $3.4 \pm 0.4$ & $8.3 \pm 0.7$ & 1.9 \\
$\mathbf{5 r}$ & $0.85 \pm 0.05$ & $0.71 \pm 0.04$ & $12 \pm 0$ & 14 \\
$\mathbf{5 s}$ & $1.1 \pm 0.2$ & $0.67 \pm 0.02$ & $>100$ & 91 \\
$\mathbf{5 t}$ & $13 \pm 5$ & $6.1 \pm 1.7$ & $\geq 99$ & 7.6 \\
$\mathbf{5 u}$ & $>100$ & $>100$ & $>100$ & - \\
$\mathbf{5 h}$ & $0.65 \pm 0.08$ & $0.60 \pm 0.18$ & $49 \pm 2$ & 76 \\
\hline a,b,c,dSee Legend to Table 1.
\end{tabular}

We next evaluated $\mathbf{5} \mathbf{h}$ in cell culture assays with a panel of other CoVs. The compound had no inhibitory effect on mouse hepatitis virus A59 (MHV-A59) and feline infectious peritonitis virus (FIPV), in CPE reduction assays in, respectively, murine fibroblast L2 cells and CrandellRees Feline Kidney cells (data not shown). HCoV-229E and FIPV belong to the alpha genus, while MHV-A59 belongs to the beta genus comprising also the highly pathogenic species SARS-CoV, MERS-CoV and SARS-CoV-2.48, 49 In VeroE6-eGFP cells infected with SARS$\mathrm{CoV}-2, \mathbf{5 h}$ and $\mathbf{5 t}$ were inactive [see reference ${ }^{50}$ for assay description]. Hence, though nicely active against HCoV-229E, 5h appeared, unfortunately, to be confined to this CoV species. Besides, when tested against a broad panel of DNA and RNA viruses, the 1,2,3-triazolo fused betulonic acid derivatives proved inactive against HIV, herpes simplex virus, vaccinia virus, adenovirus, vesicular stomatitis virus, Coxsackie B4 virus, respiratory syncytial virus, parainfluenza-3 virus, reovirus-1, Sindbis virus, Punta Toro virus, yellow fever virus and influenza virus (data not shown). 


\section{Mechanistic studies establishing nsp15 as the target of $5 \mathrm{~h}$}

Given the robust activity of the betulonic acid derivatives against HCoV-229E, we used this virus to reveal their mechanism of action and appreciate how their anti-CoV activity spectrum may be expanded. A time-of-addition experiment indicated that $\mathbf{5 h}$ acts post-entry at an early stage in viral RNA synthesis, since the molecule started to have reduced activity when added at $6 \mathrm{~h}$ p.i. (Figure 2). For comparison, the action point of the entry inhibitor bafilomycin, an inhibitor of endosomal acidification, was situated before $2 \mathrm{~h}$ p.i. K22 was still effective when added as late as $8 \mathrm{~h}$ p.i. This $\mathrm{CoV}$ inhibitor targets nsp6-dependent anchorage of the viral replication-transcription complexes (RTCs) to host cell-derived double-membrane vesicles. ${ }^{47}$

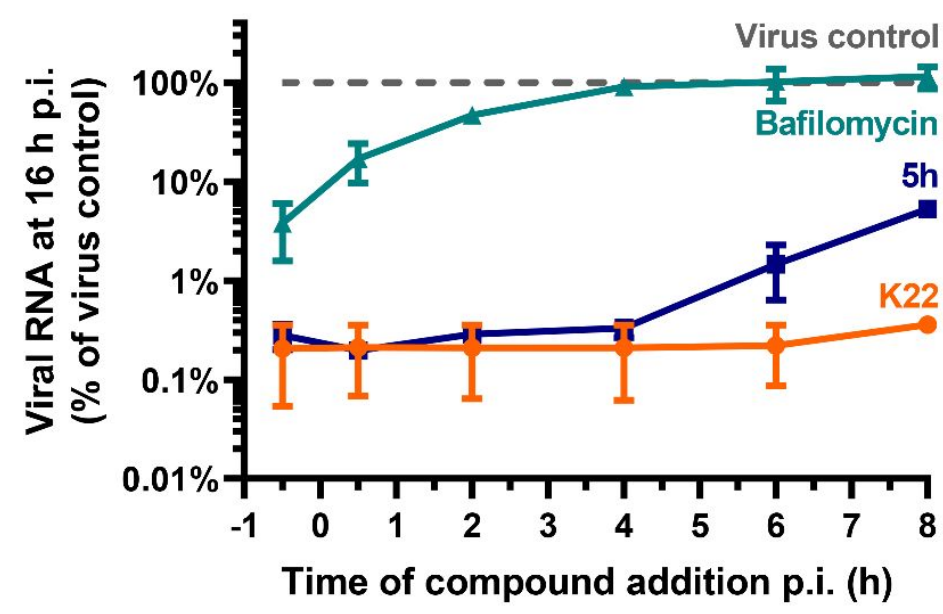

Figure 2. 5h acts post-entry at an early stage in viral RNA synthesis. Compound addition was delayed until different time points after infecting HEL cells with HCoV-229E, and viral RNA was quantified at 16 h p.i. Compound concentrations: bafilomycin $6.3 \mathrm{nM}$; $\mathbf{5 h}$ and $\mathrm{K} 22: 15 \mu \mathrm{M}$. The $\mathrm{Y}$-axis shows the viral RNA copy number relative to the virus control (mean \pm SEM of two independent experiments).

Next, we performed two independent virus passaging experiments to select $\mathbf{5 h}$-resistant viruses and identify the viral target. After three cell culture passages under increasing concentrations (up to $40 \mu \mathrm{M}$ ) of $5 \mathrm{~h}, \mathrm{HCoV}-229 \mathrm{E}$ acquired resistance. Whole virus genome sequencing revealed that this was attributed to two substitutions in nsp15, K60R (first selection) and T66I (second selection), located in the N-terminal part of this protein. For both 
mutants, $5 \mathbf{h}$ exhibited an antiviral $\mathrm{EC}_{99}$ value (= concentration producing 100 -fold reduction in virus yield) of $>40 \mu \mathrm{M}$, which is at least 14 -fold higher than the $\mathrm{EC}_{99}$ value of $2.9 \mu \mathrm{M}$ measured for wild-type (WT) virus (Figure 3A). Both mutant viruses remained fully sensitive to GS441524. The conclusion that $\mathbf{5 h}$ targets nsp15 was corroborated by determining its activity against a reverse-engineered EndoU-deficient H250A-mutant HCoV-229E, which lacks the catalytic His250 residue in the EndoU active site. ${ }^{26}$ 5h proved dramatically less active against this mutant (Figure 3B), producing a maximal reduction in virus yield of 23-fold compared to 1479-fold for WT virus. Again, GS-441524 proved equally active against nsp15-mutant and WT virus. To conclude, we established $\mathbf{5 h}$ as an inhibitor of $\mathrm{nsp} 15$, and showed that its activity is linked to residues Lys60 and Thr66 in the N-terminal part, plus His250 in the EndoU catalytic site of nsp15. This inhibition of nsp15 accords with the time-of-addition profile of $\mathbf{5 h}$ (see above), showing that the compound interferes with an early stage in viral RNA synthesis.
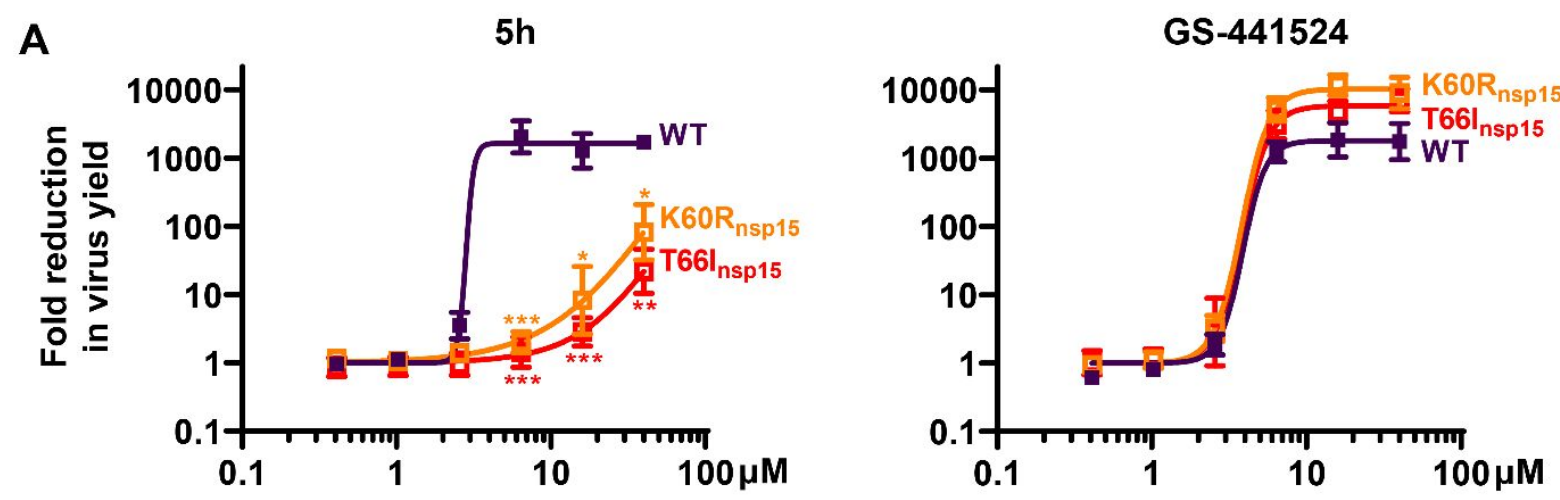

B
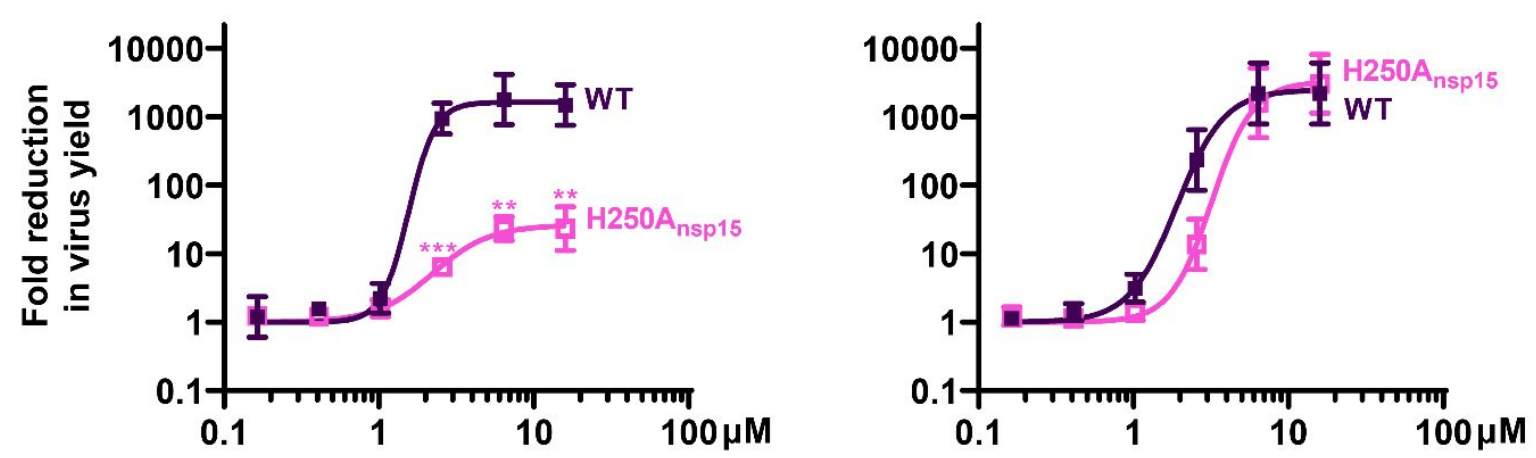

Figure 3. Mutations in nsp15 confer resistance of HCoV-229E to $5 \mathbf{h}$ (left panels), but not to GS-441524 (right panels). The graphs show the effect of the compounds on virus yield. (A) HEL cells infected with 


\begin{abstract}
5h-resistant mutants obtained by virus passaging under $\mathbf{5 h}$ and carrying substitution K60R (first selection) or T66I (second selection) in nsp15. (B) 16HBE cells infected with EndoU-deficient mutant

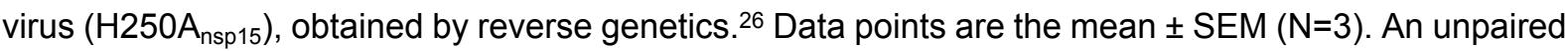
t-test (GraphPad Prism 8.4.3) was used to compare the mutant viruses to WT, and the resulting twotailed $\mathrm{p}$-values were adjusted for multiple comparisons using Holm-Sidak $(\alpha=0.05)$. ${ }^{*}, \mathrm{P}<0.05$; ${ }^{* *}, \mathrm{P}<$ $0.01 ;{ }^{* * *}, \mathrm{P}<0.001$
\end{abstract}

\title{
Binding model of $5 \mathrm{~h}$ in hexameric nsp15 protein
}

To predict the possible binding site of $\mathbf{5 h}$, the compound was docked into the $\mathbf{X}$-ray structure of hexameric nsp15 protein from HCoV-229E (PDB code: 4RS4). This hexameric structure formed by two trimers is the functional form of nsp $15 .{ }^{18}$ First, a few sites in this PDB sequence were changed to obtain the fully correct nsp15 sequence of HCoV-229E virus (see Experimental section for all details). By using a pocket-detection protocol implemented on the Site Finder module of Molecular Operating Environment (MOE) software, we identified a druggable binding pocket at the nsp15 dimer interface, surrounded by the catalytic residue His250 in the EndoU active site of one nsp15 monomer and residues Lys60 and Thr66 in the $\mathrm{N}$-terminal domain of the other monomer (Figure 4A). Next, ligand $5 \mathrm{~h}$ was placed inside the pocket and docked by using both MOE and GOLD softwares, and the common top scoring binding mode was further analyzed. This docked result indicates that the carboxylic acid of $\mathbf{5 h}$ forms hydrogen bonds with the backbone of residues Cys294 and Thr295 (Figure 4B). The importance of this interaction is supported by the observation that $\mathbf{5 u}$, the $\mathbf{5 h}$ analogue bearing a methyl instead of carboxylic acid group, lacks antiviral activity. Furthermore, the 1,2,3-triazole group of $5 \mathrm{~h}$ engages in hydrogen-bonding interactions with Thr245, explaining why the parent compounds 1 and 2 are not active against HCoV-229E. At the other side of the pocket, the aromatic ring of $\mathbf{5 h}$ makes hydrophobic contacts with Val63 and Leu65. This may explain why nearby mutations K60R and T66I yield resistance to the compound, since these substitutions may negatively affect the interactions of Val63 and Leu65, or disturb the conformation of the 
loop flanked by both residues. The structure of the substituent attached to the 1,2,3-triazole ring seems less determining, since in terms of antiviral activity, both aromatic and smaller aliphatic substituents are tolerated (see Tables 1 and 2). The one exception is the negative influence from a bulky cyclohexanemethyl group (Table 1, compound $5 \mathbf{i}$ ). Hence, the shape requirements for this substituent appear not very strict and compatible with voluminous changes that are sterically not clashing. This analysis concurs with the shallow and surfaceexposed nature of the binding pocket.

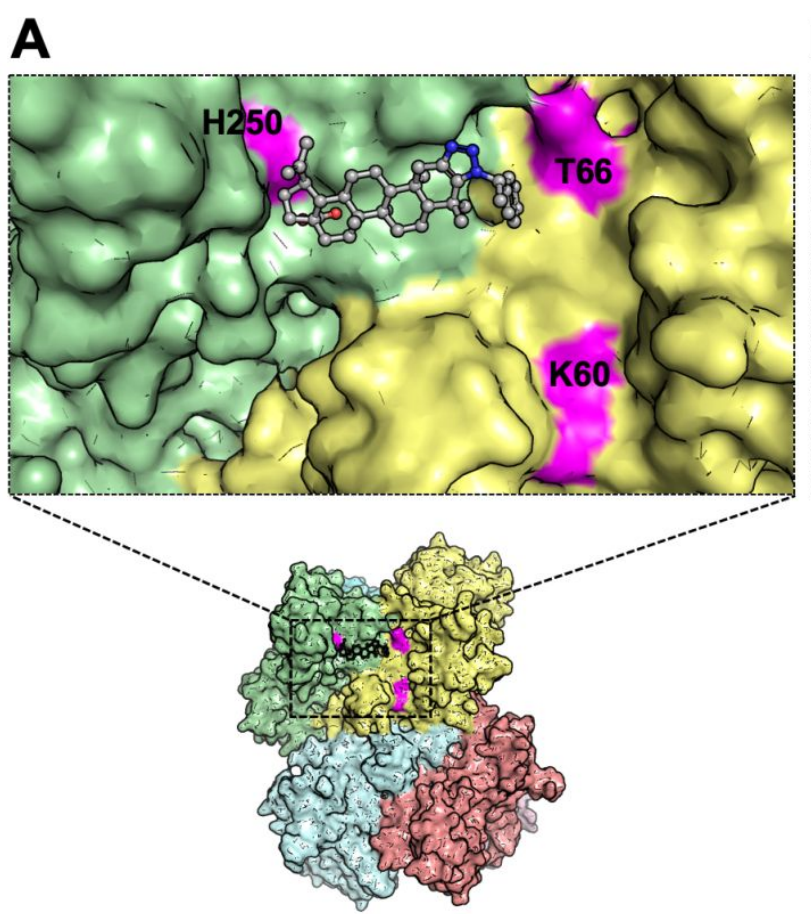

B

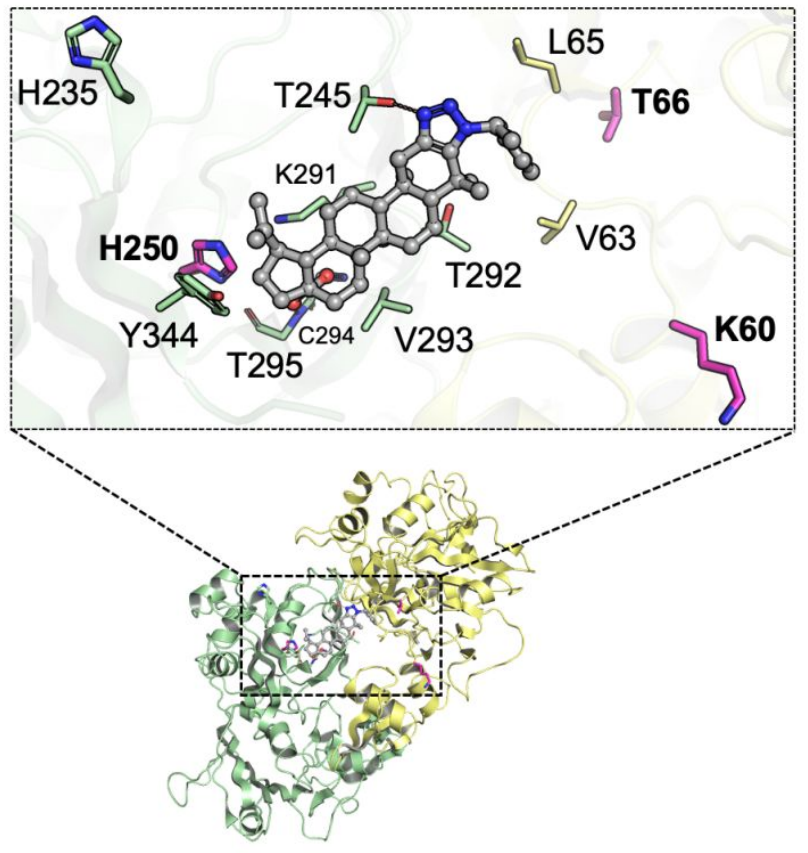

Figure 4. Binding mode of $\mathbf{5 h}$ in HCoV-229E nsp15 hexameric protein (PDB 4RS4), as predicted by docking. (A) The hydrophobic pocket lies adjacent to the EndoU catalytic centre (catalytic triad consisting of His235, His250 and Lys291) and at an nsp15 dimer interface (monomers depicted in differently colored surface). The pocket is surrounded by His250, Lys60 and Thr66, explaining why $\mathbf{5 h}$ is inactive against $\mathrm{HCoV}-229 \mathrm{E}$ viruses carrying mutations at these sites. (B) $5 \mathrm{~h}$ occupies the pocket by making hydrophobic interactions with Val293 and side chain fragments of Lys291 and Thr292. The molecule further engages in hydrogen-bonding interactions with Cys294 and Thr295 via the carboxylic acid, and with Thr245 via the 1,2,3-triazole. Additional hydrophobic interactions with Val63, Leu65 and Thr292 are made via the aromatic ring-substituted 1,2,3-triazole moiety. 
Analysis of the nsp15 sequence similarity between HCoV-229E and SARS-CoV-2 showed that a few residues in the pocket are not conserved (see Figure S1 in the Supporting Information). This explains why docking $5 \mathrm{~h}$ into the SARS-CoV-2 nsp15 hexamer was unable to identify a similar pose within the top solutions. The largest influence seems attributed to the residue at position 244/245, since substituting Thr245 (present in HCoV-229E) by GIn244 (the corresponding residue in SARS-CoV-2) abrogates a hydrogen-bond interaction with the 1,2,3triazole group of $\mathbf{5 h}$ (Figure 5). Additionally, the loop between Val/lle63 and Leu/Pro65 has a slightly different orientation in these two CoV nsp 15 proteins. Both factors may explain why $\mathbf{5 h}$ is active against $\mathrm{HCoV}-229 \mathrm{E}$, but not SARS-CoV-2. Hence, one strategy to improve the binding to SARS-CoV-2 nsp15 might be to substitute the 1,2,3-triazole by another type of ring structure. At the other side of the molecule, the carboxylic acid moiety probably needs to be kept, since it forms hydrogen bonds with both nsp 15 proteins. The fact that most of the pocket residues are conserved (Figure S1 in the Supporting Information) underscores the relevance of this nsp15 interface pocket for drug design. The role of this protein region in forming inter-monomer interactions is evident from reports that nsp15 exists as a monomer when key interactions in this region (i.e. Arg61-Glu266 in SARS-CoV nsp15 and Tyr58-Glu263 in MERS-CoV nsp15) are eliminated by mutation. ${ }^{22,51}$ When nsp 15 is unable to hexamerize, the EndoU catalytic site undergoes important structural changes that abolish RNA binding and enzymatic activity. ${ }^{52}$

A B
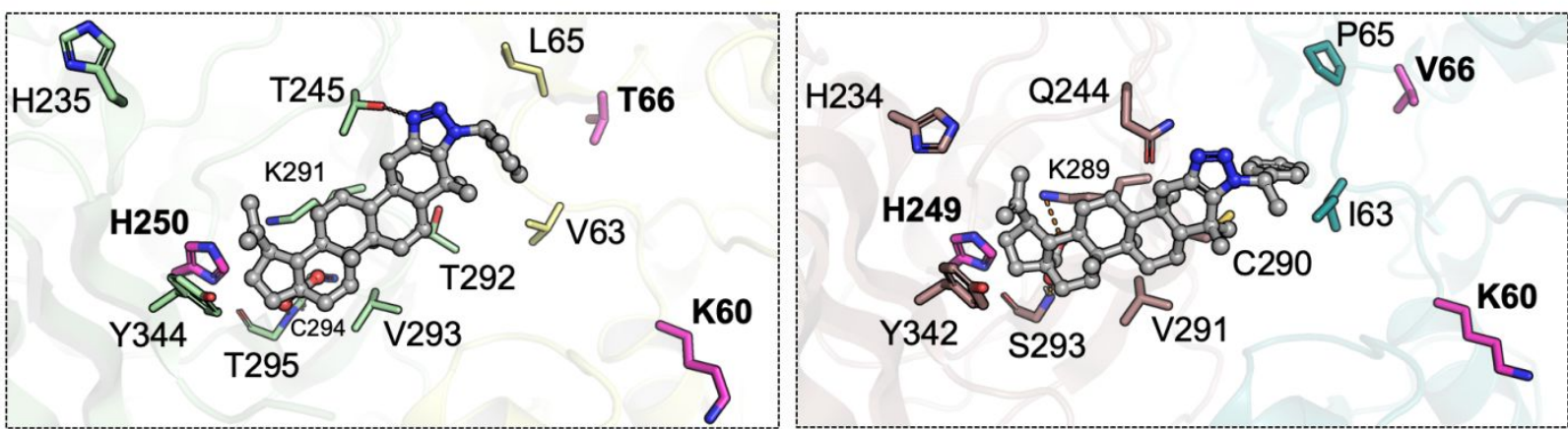

Figure 5. Comparison of the hydrophobic pocket, occupied by $\mathbf{5 h}$, in the nsp15 proteins of HCoV-229E (left; PDB 4RS4) and SARS-CoV-2 (right; PDB 7K10). The carboxylic acid of $\mathbf{5 h}$ forms hydrogen bonds 
with both nsp15 binding pockets. On the other hand, the 1,2,3-triazole group engages hydrogen-bonding interactions with the HCoV-229E nsp15 protein but is incompatible with the SARS-CoV-2 pocket.

To conclude, the nsp15 binding mode of $\mathbf{5 h}$, predicted by docking, nicely accords with the biological findings. Namely, the binding model rationalizes the requirement of the 1,2,3-triazolo function and carboxylate substituent; $5 \mathrm{~h}$ resistance of the nsp15-K60R, -T66I and $-\mathrm{H} 250 \mathrm{~A}$ mutant viruses; and lack of activity against SARS-CoV-2.

\section{CONCLUSION}

To conclude, we present the first prototype of CoV nsp15 inhibitors, having a 1,2,3-triazolo fused betulonic acid structure. The SAR analysis, resistance data and docking model provide strong evidence that lead molecule $\mathbf{5 h}$ binds to an inter-monomer nsp15 interface lying adjacent to the EndoU catalytic core. This provides an excellent basis to modify the substituents or betulonic acid scaffold, and expand the activity spectrum beyond HCoV-229E. Since $\mathbf{5 h}$ appears to interact with the catalytic His250 residue in the EndoU domain of nsp15, the molecule plausibly interferes with the role of EndoU in regulating viral dsRNA synthesis. ${ }^{28}$ To complement the findings in this report, obtained in non-immune cells, we are currently evaluating the antiviral and immunomodulatory effects of $\mathbf{5 h}$ in HCoV-229E-infected human macrophages. This may validate the intriguing concept that nsp15 inhibition could have a dual outcome, by inhibiting CoV replication and promoting host cell antiviral immunity. Since nsp15 is also considered to be an important immune evasion factor for SARS-CoV-2, further exploration of our betulonic acid skeleton and its nsp15 binding pocket is clearly warranted. 


\section{EXPERIMENTAL SECTION}

\section{Chemistry}

${ }^{1} \mathrm{H}$ and ${ }^{13} \mathrm{C}$ NMR spectra were measured on commercial instruments (Bruker Avance $300 \mathrm{MHz}$, Bruker AMX $400 \mathrm{MHz}$ and $600 \mathrm{MHz}$ ). Chemical shifts $(\delta)$ are reported in parts per million (ppm) referenced to tetramethylsilane $\left({ }^{1} \mathrm{H}\right)$, or the internal $(\mathrm{NMR})$ solvent signal $\left({ }^{13} \mathrm{C}\right)$. Melting points were determined using a Reichert Thermovar apparatus. For column chromatography, 70-230 mesh silica 60 (E. M. Merck) was used as the stationary phase. Chemicals received from commercial sources were used without further purification. Reaction dry solvents (toluene, DMF, THF) were used as received from commercial sources. TLC was carried out on Kieselgel 60 F254 plates (Merck).

Exact mass was acquired on a quadrupole orthogonal acceleration time-of-flight mass spectrometer (Synapt G2 HDMS, Waters, Milford, MA). Samples were infused at $3 \mu \mathrm{L} / \mathrm{min}$ and spectra were obtained in positive (or: negative) ionization mode with a resolution of 15000 (FWHM) using leucine enkephalin as lock mass.

All HPLC data were acquired on an Agilent 1200 HPLC with quaternary pump, autosampler, UV-DAD detector (set at 220, 230 and $240 \mathrm{~nm}$ ). Injection volume was $5 \mu \mathrm{L}$ of a dilution of 100 $\mu \mathrm{g} / \mathrm{mL}$ (sample in mobile phase). The column was a Zorbax XBD C18 column $(5 \mu \mathrm{m} ; 4.6 \mathrm{~mm} \mathrm{x}$ $150 \mathrm{~mm}$ ) and the mobile phases were: (A) $0.1 \%$ formic acid in water, and (B) methanol. The gradient consisted of: (1) $5 \mathrm{~min}$ from 50\% A / 50\% B towards 25\% A / 75\% D; (2) $15 \mathrm{~min}$ towards $0 \%$ A / 100\% B; (3) 20 min 0\% A / 100\% B. Data collection and analysis were done with Agilent Chemstation software. All tested compounds showed a purity $>95 \%$.

\section{3-Oxo-lup-20(29)-en-28-oic acid (betulonic acid, 2).}

To a solution of betulin $(50.0 \mathrm{~g}, 113 \mathrm{mmol}$; purchased from Eburon Organics BVBA) in acetone (1500 mL, use ultra-sonic bath to dissolve) was added freshly prepared Jones reagent $\left[\mathrm{Na}_{2} \mathrm{Cr}_{2} \mathrm{O}_{7},(66.5 \mathrm{~g}, 226 \mathrm{mmol})\right.$ and $\mathrm{H}_{2} \mathrm{SO}_{4}(60 \mathrm{~mL})$ in water $\left.(500 \mathrm{~mL})\right]$ during $1 \mathrm{~h}$ in an ice bath. 
The reaction mixture was allowed to warm to room temperature and stirring was continued for $6 \mathrm{~h}$ fellow with TLC. First, $\mathrm{MeOH}$ was added and then water to the reaction mixture. Precipitate was filtered off and washed with water $(500 \mathrm{~mL})$. The crude product was dried in a vacuum oven, dissolved to $\mathrm{Et}_{2} \mathrm{O}(600 \mathrm{~mL})$ and washed with water $(300 \mathrm{~mL}), 7.5 \%$ hydrochloric acid $(200 \mathrm{~mL})$, water $(200 \mathrm{~mL})$, saturated aqueous $\mathrm{NaHCO}_{3}$ solution $(200 \mathrm{~mL})$ and water $(200 \mathrm{~mL})$. The crude reaction mixture was purified by column chromatography (silica gel) whereas eluent was used a mixture of heptane and ethyl acetate $70: 30$ to afford betulonic acid $23 \mathrm{~g} 45 \%$ yield. Spectroscopic data for betulonic acid was consistent with previously reported data for this compound. ${ }^{43}$

\section{3-0xo-lupan-28-oic acid (dihydro-betulonic acid).}

Betulonic acid (180 mg, $0.396 \mathrm{mmol}, 1.0$ equiv.) was dissolved in a mixture of $\mathrm{MeOH} / \mathrm{THF}(2 / 6$ $\mathrm{mL}) .10 \% \mathrm{Pd}(\mathrm{OH})_{2}(30 \mathrm{mg})$ was added under $\mathrm{N}_{2}$ atmosphere. This atmosphere was replaced by $\mathrm{H}_{2}$ atmosphere. The reaction was stirred under $\mathrm{H}_{2}$ atmosphere for $78 \mathrm{~h}$, then filtered through celite and washed with $\mathrm{CHCl}_{3}$ to afford a white solid. The residue obtained was purified by silica gel column chromatography using $100 \%$ chloroform as eluent to afford dihydro-betulonic acid (quantitative yield) as a white amorphous powder. The spectra proved the identity of the compound by comparing the data with the literature..$^{53}$

\section{General Procedure}

To a dried screw-capped reaction tube equipped with a magnetic stirring bar was added betulonic acid, amine, 4-nitrophenyl azide, $4 \AA$ molecular sieves $(50 \mathrm{mg})$. The mixture was dissolved in the proper solvent (toluene, DMF) and stirred at $100{ }^{\circ} \mathrm{C}$ for $12-72$ hours. The reaction was monitored using TLC with the plate first developed with DCM then different ratios petroleum ether/ethyl acetate 7:3, 6:4 were used depending on the substrates. For visualization of TLC plates was used $5 \% \mathrm{H}_{2} \mathrm{SO}_{4}$ in ethanol, for more sensitive detection was used cerium-ammonium-molybdate after heating to $150-200^{\circ} \mathrm{C}$. The crude reaction mixture 
was then directly purified by column chromatography (silica gel), at first with $\mathrm{CH}_{2} \mathrm{Cl}_{2}$ as an eluent to remove all 4-nitroaniline formed during the reaction, followed by using a mixture of petroleum ether and ethyl acetate as eluent to afford the betulonic acid 1,2,3-triazole derivatives.

\section{1'-(3,4,5-Trimethoxybenzyl)-1 $H^{\prime}$-lup-2-eno-[2,3-d]-[1,2,3]-triazole-28-oic acid (5a).}

Betulonic acid (100 mg, 1 equiv., $0.220 \mathrm{mmol}$ ), 3,4,5-trimethoxybenzylamine (56 mg, 1.3 equiv., $0.286 \mathrm{mmol}$ ), 4-nitrophenyl azide (36 mg, 1 equiv., $0.220 \mathrm{mmol}$ ), $4 \AA$ molecular sieves $(50 \mathrm{mg})$ and toluene $(0.5 \mathrm{~mL})$. Reaction time is overnight. The product was purified by flash column chromatography (first washed with $\mathrm{CH}_{2} \mathrm{Cl}_{2}$ followed by petroleum ether : EtOAc 9:1 $\rightarrow$ 6:4 ) affording 5a (122 mg, 84\% yield) as off white crystals. m.p. $152{ }^{\circ} \mathrm{C} .{ }^{1} \mathrm{H}$ NMR $(400 \mathrm{MHz}$, $\left.\mathrm{CDCl}_{3}\right) \delta 6.25(\mathrm{~s}, 2 \mathrm{H}), 5.57(\mathrm{~s}, 2 \mathrm{H}), 4.76(\mathrm{~s}, 1 \mathrm{H}), 4.64(\mathrm{~s}, 1 \mathrm{H}), 3.81(\mathrm{~s}, 3 \mathrm{H}), 3.77(\mathrm{~s}, 6 \mathrm{H}), 3.04$ (m, 1H), $2.96(\mathrm{~d}, J=15.4 \mathrm{~Hz}, 1 \mathrm{H}), 2.32-2.15(\mathrm{~m}, 3 \mathrm{H}), 2.05-1.94(\mathrm{~m}, 2 \mathrm{H}), 1.77-1.64(\mathrm{~m}$, 5H), $1.59-1.40(\mathrm{~m}, 11 \mathrm{H}), 1.20(\mathrm{~s}, 7 \mathrm{H}), 1.03(\mathrm{~s}, 3 \mathrm{H}), 1.00(\mathrm{~s}, 3 \mathrm{H}), 0.97(\mathrm{~s}, 3 \mathrm{H}), 0.77(\mathrm{~s}, 3 \mathrm{H})$. ${ }^{13} \mathrm{C}$ NMR $\left(101 \mathrm{MHz}, \mathrm{CDCl}_{3}\right) \delta 180.9,153.5,150.2,141.9,138.0,137.4,132.1,109.8,103.5$, $60.8,56.3,56.1,54.6,52.8,49.3,49.1,46.8,42.4,40.5,38.9,38.5,37.0,33.7,33.3,32.0$, $30.5,29.8,29.7,28.7,25.5,21.3,21.3,19.4,18.9,16.0,15.7,14.6$. HRMS $\left(\mathrm{ESI}^{+}\right): \mathrm{m} / \mathrm{z}$ calculated for $\mathrm{C}_{40} \mathrm{H}_{57} \mathrm{~N}_{3} \mathrm{O}_{5} \mathrm{H}[\mathrm{M}+\mathrm{H}]^{+}: 660.4370$, found 660.4384 .

\section{1'-(3,5-Dimethoxybenzyl)-1H'-lup-2-eno-[2,3-d]-[1,2,3]-triazole-28-oic acid (5b).}

Betulonic acid (100 mg, 1 equiv., $0.220 \mathrm{mmol}$ ), 3,5-dimethoxybenzylamine (48 mg, 1.3 equiv., $0.286 \mathrm{mmol}$ ), 4-nitrophenyl azide (36 mg, 1 equiv., $0.220 \mathrm{mmol}), 4 \AA$ molecular sieves $(50 \mathrm{mg})$ and toluene $(0.5 \mathrm{~mL})$. Reaction time is overnight. The product was purified by flash column chromatography (first washed with $\mathrm{CH}_{2} \mathrm{Cl}_{2}$ followed by petroleum ether : EtOAc 9:1 $\rightarrow$ 6:4 ) affording 5b (126 mg, 92\% yield) as off white crystals. m.p. $159{ }^{\circ} \mathrm{C} .{ }^{1} \mathrm{H}$ NMR $\left(400 \mathrm{MHz}, \mathrm{CDCl}_{3}\right)$ $\delta 6.34(\mathrm{~s}, 1 \mathrm{H}), 6.16(\mathrm{~s}, 2 \mathrm{H}), 5.57(\mathrm{~s}, 2 \mathrm{H}), 4.76(\mathrm{~s}, 1 \mathrm{H}), 4.64(\mathrm{~s}, 1 \mathrm{H}), 3.71(\mathrm{~s}, 6 \mathrm{H}), 3.08-2.99$ (m, 1H), $2.95(\mathrm{~d}, J=15.4 \mathrm{~Hz}, 1 \mathrm{H}), 2.32-2.14(\mathrm{~m}, 3 \mathrm{H}), 2.05-1.94(\mathrm{~m}, 2 \mathrm{H}), 1.79-1.62(\mathrm{~m}$, $5 \mathrm{H}), 1.60-1.33(\mathrm{~m}, 11 \mathrm{H}), 1.29-1.10(\mathrm{~m}, 7 \mathrm{H}), 1.03(\mathrm{~s}, 3 \mathrm{H}), 1.00(\mathrm{~s}, 3 \mathrm{H}), 0.98(\mathrm{~s}, 3 \mathrm{H}), 0.77$ 
(s, 3H). ${ }^{13} \mathrm{C}$ NMR $\left(101 \mathrm{MHz}, \mathrm{CDCl}_{3}\right) \delta 181.6,161.1,150.2,141.8,138.9,138.0,109.8,104.4$, $99.6,56.4,55.3,54.5,52.8,49.2,49.2,46.9,42.4,40.5,38.9,38.5,38.3,37.0,33.7,33.3$, $32.0,30.6,29.8,28.7,25.5,21.3,21.2,19.4,18.9,16.0,15.7,14.6$. HRMS $\left(E S I^{+}\right): \mathrm{m} / \mathrm{z}$ calculated for $\mathrm{C}_{39} \mathrm{H}_{55} \mathrm{~N}_{3} \mathrm{O}_{4} \mathrm{H}[\mathrm{M}+\mathrm{H}]^{+}: 630.4265$, found 630.4274 .

\section{1'-(Pyridin-4-ylmethyl)-1 $H^{\prime}$-lup-2-eno-[2,3-d]-[1,2,3]-triazole-28-oic acid (5c).}

Betulonic acid (100 mg, 1 equiv., $0.220 \mathrm{mmol})$, 4-(aminomethyl)pyridine (31 mg, 1.3 equiv., $0.286 \mathrm{mmol}$ ), 4-nitrophenyl azide (36 mg, 1 equiv., $0.220 \mathrm{mmol}), 4 \AA$ molecular sieves $(50 \mathrm{mg})$ and toluene $(0.5 \mathrm{~mL})$. Reaction time is overnight. The product was purified by flash column chromatography (first washed with $\mathrm{CH}_{2} \mathrm{Cl}_{2}$ followed by petroleum ether : EtOAc 9:1 $\rightarrow$ 6:4 ) affording 5c (97 mg, 78\% yield) as off white crystals. m.p $172{ }^{\circ} \mathrm{C} .{ }^{1} \mathrm{H}$ NMR $\left(400 \mathrm{MHz}, \mathrm{CDCl}_{3}\right)$ $\delta 8.56(\mathrm{~d}, J=5.6 \mathrm{~Hz}, 2 \mathrm{H}), 6.93(\mathrm{~d}, J=5.6 \mathrm{~Hz}, 2 \mathrm{H}), 5.66(\mathrm{~s}, 2 \mathrm{H}), 4.76(\mathrm{~s}, 1 \mathrm{H}), 4.64(\mathrm{~s}, 1 \mathrm{H}), 3.06$ (m, 1H), $2.97(\mathrm{~d}, J=15.4 \mathrm{~Hz}, 1 \mathrm{H}), 2.36-2.15(\mathrm{~m}, 3 \mathrm{H}), 2.06-1.95(\mathrm{~m}, 2 \mathrm{H}), 1.83-1.64(\mathrm{~m}$, $5 \mathrm{H}), 1.60-1.37(\mathrm{~m}, 11 \mathrm{H}), 1.32-1.21(\mathrm{~m}, 7 \mathrm{H}), 1.16(\mathrm{~s}, 3 \mathrm{H}), 1.01(\mathrm{~m}, 3 \mathrm{H}), 1.00(\mathrm{~m}, 3 \mathrm{H}), 0.77$ (s, 3H). ${ }^{13} \mathrm{C}$ NMR $\left(101 \mathrm{MHz}, \mathrm{CDCl}_{3}\right) \delta 180.6,150.4,149.8,146.1,142.3,138.3,121.2,109.7$, $56.3,54.4,51.6,49.2,49.2,46.9,42.4,40.5,39.0,38.4,38.2,37.0,33.6,33.2,32.1,30.6$, 29.8, 29.6, 28.8, 25.4, 21.5, 21.4, 19.4, 18.8, 16.0, 15.7, 14.6. HRMS (ESI+): m/z calculated for $\mathrm{C}_{36} \mathrm{H}_{50} \mathrm{~N}_{4} \mathrm{O}_{2} \mathrm{H}[\mathrm{M}+\mathrm{H}]^{+}:$571.4006, found 571.4013 .

\section{1'-(4-Methylbenzyl)-1H'-lup-2-eno-[2,3-d]-[1,2,3]-triazole-28-oic acid (5d).}

Betulonic acid (100 mg, 1 equiv., $0.220 \mathrm{mmol}$ ), 4-methylbenzylamine (35 mg, 1.3 equiv., 0.286 mmol), 4-nitrophenyl azide (36 mg, 1 equiv., $0.220 \mathrm{mmol}$ ), $4 \AA$ molecular sieves (50 mg) and toluene $(0.5 \mathrm{~mL})$. Reaction time is overnight. The product was purified by flash column chromatography (first washed with $\mathrm{CH}_{2} \mathrm{Cl}_{2}$ followed by petroleum ether : EtOAc 9:1 $\rightarrow$ 6:4 ) affording $5 \mathbf{d}\left(115 \mathrm{mg}, 90 \%\right.$ yield) as off white crystals. m.p. $310^{\circ} \mathrm{C} .{ }^{1} \mathrm{H} \mathbf{N M R}\left(600 \mathrm{MHz}, \mathrm{CDCl}_{3}\right)$ $\delta 7.09$ (d, J = 7.9 Hz, 2H), $6.92(\mathrm{~d}, J=7.9 \mathrm{~Hz}, 2 \mathrm{H}), 5.59$ (s, br, 2H), 4.75 (s, 1H), $4.63(\mathrm{~s}, 1 \mathrm{H})$, $3.03(\mathrm{~m}, 1 \mathrm{H}), 2.95(\mathrm{~d}, J=15.4 \mathrm{~Hz}, 1 \mathrm{H}), 2.32-2.23(\mathrm{~m}, 5 \mathrm{H}), 2.17(\mathrm{~d}, J=15.4 \mathrm{~Hz}, 1 \mathrm{H}), 2.05-$ $1.94(\mathrm{~m}, 2 \mathrm{H}), 1.80-1.62(\mathrm{~m}, 5 \mathrm{H}), 1.50(\mathrm{~m} \mathrm{11H}), 1.22-1.09(\mathrm{~m}, 7 \mathrm{H}), 1.03(\mathrm{~s}, 3 \mathrm{H}), 0.99(\mathrm{~s}$, 
3H), 0.97 (s, 3H), 0.77 (s, 3H). ${ }^{13} \mathrm{C}$ NMR $\left(101 \mathrm{MHz}, \mathrm{CDCl}_{3}\right) \delta 181.8,150.2,141.7,138.0,137.4$, 133.3, 129.3, 126.3, 109.8, 56.4, 54.5, 52.6, 49.2, 49.1, 46.8, 42.4, 40.8, 40.5, 38.9, 38.4, 38.2, $37.0,33.7,33.3,32.0,30.5,29.7,28.7,28.4,25.4,23.8,21.3,21.3,21.0,20.8,19.4,18.9$, 17.5, 17.2, 16.0, 15.6, 14.6. HRMS $\left(\mathrm{ESI}^{+}\right): \mathrm{m} / \mathrm{z}$ calculated for $\mathrm{C}_{38} \mathrm{H}_{53} \mathrm{~N}_{3} \mathrm{O}_{2} \mathrm{H}[\mathrm{M}+\mathrm{H}]^{+}: 584.4210$, found 584.4217 .

\section{1'-(4-Fluorobenzyl)-1 $H^{\prime}$-lup-2-eno-[2,3-d]-[1,2,3]-triazole-28-oic acid (5e).}

Betulonic acid (100 mg, 1 equiv., $0.220 \mathrm{mmol}$ ), 4-fluorobenzylamine (36 mg, 1.3 equiv., 0.286 mmol), 4-nitrophenyl azide (36 mg, 1 equiv., $0.220 \mathrm{mmol}$ ), $4 \AA$ molecular sieves (50 mg) and toluene $(0.5 \mathrm{~mL})$. Reaction time is overnight. The product was purified by flash column chromatography (first washed with $\mathrm{CH}_{2} \mathrm{Cl}_{2}$ followed by petroleum ether : EtOAc 9:1 $\rightarrow$ 6:4 ) affording 5 e (110 mg, 85\% yield) as off white crystals. m.p. $309^{\circ} \mathrm{C} .{ }^{1} \mathrm{H}$ NMR $\left(400 \mathrm{MHz}, \mathrm{CDCl}_{3}\right)$ $\delta 7.00(\mathrm{~m}, 4 \mathrm{H}), 5.60(\mathrm{~s}, 2 \mathrm{H}), 4.76(\mathrm{~s}, 1 \mathrm{H}), 4.64(\mathrm{~s}, 1 \mathrm{H}), 3.08-2.99(\mathrm{~m}, 1 \mathrm{H}), 2.95(\mathrm{~d}, J=15.3$ $\mathrm{Hz}, 1 \mathrm{H}), 2.33-2.14(\mathrm{~m}, 3 \mathrm{H}), 2.06-1.93(\mathrm{~m}, 2 \mathrm{H}), 1.82-1.62(\mathrm{~m}, 5 \mathrm{H}), 1.61-1.31(\mathrm{~m}, 11 \mathrm{H})$, $1.30-1.10(\mathrm{~m}, 7 \mathrm{H}), 1.08(\mathrm{~s}, 3 \mathrm{H}), 1.02(\mathrm{~s}, 3 \mathrm{H}), 1.00(\mathrm{~s}, 3 \mathrm{H}), 0.77$ (s, 3H). ${ }^{13} \mathrm{C}$ NMR (101 MHz, $\left.\mathrm{CDCl}_{3}\right) \delta 181.1,163.5,161.0,150.2,142.0,137.9,132.2,132.2,128.2,128.1,115.8,115.5$, $109.8,56.3,54.5,52.1,49.2,49.2,46.9,42.4,40.5,38.9,38.5,38.3,37.0,33.7,33.3,32.0$, $30.5,29.8,28.7,25.4,21.3,21.3,19.4,18.8,16.0,15.7,14.6$. HRMS (ESI $): m / z$ calculated for $\mathrm{C}_{37} \mathrm{H}_{50} \mathrm{FN}_{3} \mathrm{O}_{2} \mathrm{H}[\mathrm{M}+\mathrm{H}]^{+}:$588.3959, found 588.3969.

\section{1'-(4-Trifluoromethylbenzyl)-1H'-lup-2-eno-[2,3-d]-[1,2,3]-triazole-28-oic acid (5f).}

Betulonic acid (100 mg, 1 equiv., $0.220 \mathrm{mmol}$ ), 4-(trifluoromethyl)benzylamine (50 mg, 1.3 equiv., $0.286 \mathrm{mmol}$ ), 4-nitrophenyl azide (36 mg, 1 equiv., $0.220 \mathrm{mmol}$ ), $4 \AA$ molecular sieves (50 $\mathrm{mg})$ and toluene $(0.5 \mathrm{~mL})$. Reaction time is overnight. The product was purified by flash column chromatography (first washed with $\mathrm{CH}_{2} \mathrm{Cl}_{2}$ followed by petroleum ether : EtOAc 9:1 $\rightarrow$ 6:4 ) affording $\mathbf{5 f}\left(112 \mathrm{mg}, 80 \%\right.$ yield) as off white crystals. m.p. $315^{\circ} \mathrm{C} .{ }^{1} \mathbf{H}$ NMR $(400 \mathrm{MHz}$, $\left.\mathrm{CDCl}_{3}\right) \delta 7.56(\mathrm{~d}, J=8.0 \mathrm{~Hz}, 2 \mathrm{H}), 7.11(\mathrm{~d}, J=8.0 \mathrm{~Hz}, 2 \mathrm{H}), 5.69(\mathrm{~s}, 2 \mathrm{H}), 4.76(\mathrm{~s}, 1 \mathrm{H}), 4.64(\mathrm{~s}$, 1H), $3.02(\mathrm{~m}, 2 \mathrm{H}), 2.34-2.16(\mathrm{~m}, 3 \mathrm{H}), 2.07-1.94(\mathrm{~m}, 2 \mathrm{H}), 1.82-1.64(\mathrm{~m}, 5 \mathrm{H}), 1.59-1.38$ 
$(\mathrm{m}, 11 \mathrm{H}), 1.18(\mathrm{~m}, 7 \mathrm{H}), 1.02(\mathrm{~s}, 3 \mathrm{H}), 1.00(\mathrm{~s}, 3 \mathrm{H}), 0.97(\mathrm{~s}, 3 \mathrm{H}), 0.78(\mathrm{~s}, 3 \mathrm{H}) .{ }^{13} \mathrm{C}$ NMR (101 $\left.\mathrm{MHz}, \mathrm{CDCl}_{3}\right) \delta 181.4,150.2,142.1,140.5,138.2,126.6,125.7,125.7,109.8,56.4,54.5,52.2$, $49.3,49.1,46.9,42.4,40.8,40.5,38.9,38.5,38.2,37.0,33.8,33.6,33.3,32.0,30.5,29.8$, $29.7,28.8,28.4,25.4,23.8,21.4,21.3,20.8,20.5,19.4,18.8,17.5,17.3,16.1,15.7,14.6,7.9$. HRMS $\left(E S I^{+}\right): \mathrm{m} / \mathrm{z}$ calculated for $\mathrm{C}_{38} \mathrm{H}_{50} \mathrm{~F}_{3} \mathrm{~N}_{3} \mathrm{O}_{2} \mathrm{H}[\mathrm{M}+\mathrm{H}]^{+}: 638.3927$, found 638.3939.

\section{1'-(4-Dimethylaminobenzyl)-1 $H^{\prime}$-Iup-2-eno-[2,3-d]-[1,2,3]-triazole-28-oic acid (5g).}

Betulonic acid (100 mg, 1 equiv., $0.220 \mathrm{mmol}$ ), 4-(dimethylamino)benzylamine (43 mg, 1.3 equiv., $0.286 \mathrm{mmol}$ ), 4-nitrophenyl azide (36 mg, 1 equiv., $0.220 \mathrm{mmol}$ ), $4 \AA$ molecular sieves $(50 \mathrm{mg})$ and toluene $(0.5 \mathrm{~mL})$. Reaction time is overnight. The product was purified by flash column chromatography (first washed with $\mathrm{CH}_{2} \mathrm{Cl}_{2}$ followed by petroleum ether : EtOAc 9:1 $\rightarrow$ 6:4 ) affording $\mathbf{5 g}\left(112 \mathrm{mg}, 80 \%\right.$ yield) as off white crystals. m.p. $190{ }^{\circ} \mathrm{C} .{ }^{1} \mathbf{H}$ NMR $(400 \mathrm{MHz}$, $\left.\mathrm{CDCl}_{3}\right) \delta 6.97(\mathrm{~d}, J=8.3 \mathrm{~Hz}, 2 \mathrm{H}), 6.64(\mathrm{~d}, J=8.3 \mathrm{~Hz}, 2 \mathrm{H}), 5.52(\mathrm{~s}, 2 \mathrm{H}), 4.76(\mathrm{~s}, 1 \mathrm{H}), 4.64(\mathrm{~s}$, $1 \mathrm{H}), 3.10-2.84(\mathrm{~m}, 9 \mathrm{H}), 2.33-2.11(\mathrm{~m}, 3 \mathrm{H}), 1.99(\mathrm{~m}, 2 \mathrm{H}), 1.81-1.62(\mathrm{~m}, 5 \mathrm{H}), 1.56-1.34$ $(\mathrm{m}, 11 \mathrm{H}), 1.25-1.15(\mathrm{~m}, 7 \mathrm{H}), 1.06(\mathrm{~s}, 3 \mathrm{H}), 0.99(\mathrm{~s}, 3 \mathrm{H}), 0.97(\mathrm{~s}, 3 \mathrm{H}), 0.76(\mathrm{~s}, 3 \mathrm{H}) .{ }^{13} \mathrm{C}$ NMR $\left(101 \mathrm{MHz}, \mathrm{CDCl}_{3}\right) \delta 181.4,150.2,150.1,141.6,137.7,127.6,123.9,112.5,109.8,56.4,54.6$, $52.6,49.2,49.1,46.8,42.4,40.5,40.5,38.9,38.9,38.4,38.3,37.0,33.7,33.3,32.1,30.5$, 29.8, 28.7, 25.5, 23.8, 21.3, 21.3, 20.8, 19.4, 18.9, 16.0, 15.6, 14.6. HRMS $\left(\mathrm{ESI}^{+}\right): \mathrm{m} / \mathrm{z}$ calculated for $\mathrm{C}_{39} \mathrm{H}_{56} \mathrm{~N}_{4} \mathrm{O}_{2} \mathrm{H}[\mathrm{M}+\mathrm{H}]^{+}:$613.4475, found 613.4480 .

\section{1'-((S)-1-Phenylethyl)-1H'-lup-2-eno-[2,3-d]-[1,2,3]-triazole-28-oic acid (5h).}

Betulonic acid (100 mg, 1 equiv., $0.220 \mathrm{mmol}$ ), (S)-(-)- $\alpha$-methylbenzylamine (35 mg, 1.3 equiv, $0.286 \mathrm{mmol}$ ), 4-nitrophenyl azide (36 mg, 1 equiv., $0.220 \mathrm{mmol}), 4 \AA$ molecular sieves $(50 \mathrm{mg})$ and toluene $(0.5 \mathrm{~mL})$. Reaction time is overnight. The product was purified by flash column chromatography (first washed with $\mathrm{CH}_{2} \mathrm{Cl}_{2}$ followed by petroleum ether : EtOAc 9:1 $\rightarrow$ 6:4 ) affording $5 \mathrm{~h}$ (107 mg, $84 \%$ yield) as off white crystals. m.p. $327^{\circ} \mathrm{C} .{ }^{1} \mathrm{H}$ NMR $\left(400 \mathrm{MHz}, \mathrm{CDCl}_{3}\right)$ $\delta 7.30-7.21(\mathrm{~m}, 3 \mathrm{H}), 7.13(\mathrm{~d}, J=7.2 \mathrm{~Hz}, 2 \mathrm{H}), 5.73(\mathrm{~m}, 1 \mathrm{H}), 4.76(\mathrm{~s}, 1 \mathrm{H}), 4.64(\mathrm{~s}, 1 \mathrm{H}), 3.00$ 
(m, 2H), $2.33-2.12(\mathrm{~m}, 3 \mathrm{H}), 2.07-1.92(\mathrm{~m}, 5 \mathrm{H}), 1.81-1.62(\mathrm{~m}, 5 \mathrm{H}), 1.58-1.37(\mathrm{~m}, 11 \mathrm{H})$, $1.14(\mathrm{~m}, 7 \mathrm{H}), 1.00(\mathrm{~s}, 6 \mathrm{H}), 0.96(\mathrm{~s}, 3 \mathrm{H}), 0.72(\mathrm{~s}, 3 \mathrm{H}) .{ }^{13} \mathrm{C} \mathrm{NMR}\left(101 \mathrm{MHz}, \mathrm{CDCl}_{3}\right) \delta$ 180.6, $150.2,141.8,141.1,137.6,128.6,127.5,126.1,109.8,59.1,56.3,54.8,49.3,49.1,46.8,42.4$, $40.5,38.8,38.4,37.0,33.6,33.3,32.0,30.5,29.7,29.7,28.6,25.4,23.3,21.4,21.3,19.4$, 19.0, 15.9, 15.6, 14.6. HRMS (ESI+): $\mathrm{m} / \mathrm{z}$ calculated for $\mathrm{C}_{38} \mathrm{H}_{53} \mathrm{~N}_{3} \mathrm{O}_{2} \mathrm{H}[\mathrm{M}+\mathrm{H}]^{+}: 584.4210$, found 584.4218.

\section{1'-(Cyclohexylmethyl)-1 $H^{\prime}$-lup-2-eno-[2,3-d]-[1,2,3]-triazole-28-oic acid (5i).}

Betulonic acid (100 mg, 1 equiv., $0.220 \mathrm{mmol}$ ), cyclohexanemethylamine (33 mg, 1.3 equiv., $0.286 \mathrm{mmol}$ ), 4-nitrophenyl azide (36 mg, 1 equiv., $0.220 \mathrm{mmol}), 4 \AA$ molecular sieves $(50 \mathrm{mg})$ and toluene $(0.5 \mathrm{~mL})$. Reaction time is overnight. The product was purified by flash column chromatography (first washed with $\mathrm{CH}_{2} \mathrm{Cl}_{2}$ followed by petroleum ether : EtOAc 9:1 $\rightarrow$ 6:4 ) affording $5 \mathbf{i}$ (103 mg, 82\% yield) as off white crystals. m.p. $338{ }^{\circ} \mathrm{C} .{ }^{1} \mathrm{H} \mathbf{N M R}\left(600 \mathrm{MHz}, \mathrm{CDCl}_{3}\right)$ $\delta 4.76(\mathrm{~s}, 1 \mathrm{H}), 4.64(\mathrm{~s}, 1 \mathrm{H}), 4.09(\mathrm{~m}, 2 \mathrm{H}), 3.04(\mathrm{~m}, 1 \mathrm{H}), 2.92(\mathrm{~m}, 1 \mathrm{H}), 2.33-2.21(\mathrm{~m}, 2 \mathrm{H}), 2.13$ (d, $J=15.3 \mathrm{~Hz}, 1 \mathrm{H}), 2.07-1.95(\mathrm{~m}, 2 \mathrm{H}), 1.79-1.64(\mathrm{~m}, 10 \mathrm{H}), 1.61-1.34(\mathrm{~m}, 11 \mathrm{H}), 1.32-$ $1.19(\mathrm{~m}, 10 \mathrm{H}), 1.18-1.08(\mathrm{~m}, 5 \mathrm{H}), 1.00(\mathrm{~s}, 3 \mathrm{H}), 0.99(\mathrm{~s}, 3 \mathrm{H}), 0.77(\mathrm{~s}, 3 \mathrm{H}) .{ }^{13} \mathrm{C}$ NMR $(101 \mathrm{MHz}$, $\left.\mathrm{CDCl}_{3}\right) \delta 181.7,150.2,140.9,137.8,109.8,56.4,55.6,54.7,49.2,49.2,46.9,42.4,40.5,38.8$, $38.6,38.5,38.2,37.0,33.7,33.3,32.1,31.0,30.6,29.8,28.9,26.3,25.7,25.4,21.5,21.3$, 19.4, 18.9, 16.0, 15.7, 14.6. HRMS (ESI+): $\mathrm{m} / \mathrm{z}$ calculated for $\mathrm{C}_{37} \mathrm{H}_{57} \mathrm{~N}_{3} \mathrm{O}_{2} \mathrm{H}[\mathrm{M}+\mathrm{H}]^{+}: 576.4523$, found 576.4529 .

\section{1'-(Benzo[d][1,3]dioxol-5-ylmethyl)-1 H'-lup-2-eno-[2,3-d]-[1,2,3]-triazole-28-oic acid (5j).}

Betulonic acid (100 mg, 1 equiv., $0.220 \mathrm{mmol}$ ), piperonylamine (43 mg, 1.3 equiv., 0.286 mmol), 4-nitrophenyl azide (36 mg, 1 equiv., $0.220 \mathrm{mmol}$ ), $4 \AA$ molecular sieves (50 mg) and toluene $(0.5 \mathrm{~mL})$. Reaction time is overnight. The product was purified by flash column chromatography (first washed with $\mathrm{CH}_{2} \mathrm{Cl}_{2}$ followed by petroleum ether: EtOAc 9:1 $\rightarrow$ 6:4 ) affording $5 \mathbf{j}$ (105 mg, $78 \%$ yield) as off white crystals. m.p. $313^{\circ} \mathrm{C} .{ }^{1} \mathrm{H} \mathbf{N M R}\left(300 \mathrm{MHz}, \mathrm{CDCl}_{3}\right)$ 
$\delta 6.72(\mathrm{~d}, J=7.9 \mathrm{~Hz}, 1 \mathrm{H}), 6.59-6.48(\mathrm{~m}, 2 \mathrm{H}), 5.93(\mathrm{~d}, J=0.9 \mathrm{~Hz}, 2 \mathrm{H}), 5.53(\mathrm{~s}, 2 \mathrm{H}), 4.76$ (s, $1 \mathrm{H}), 4.64(\mathrm{~s}, 1 \mathrm{H}), 3.10-2.89(\mathrm{~m}, 2 \mathrm{H}), 2.35-2.11(\mathrm{~m}, 3 \mathrm{H}), 1.99(\mathrm{~m}, 2 \mathrm{H}), 1.83-1.62(\mathrm{~m}, 5 \mathrm{H})$, $1.61-1.33(\mathrm{~m}, 11 \mathrm{H}), 1.33-1.08(\mathrm{~m}, 7 \mathrm{H}), 1.05(\mathrm{~s}, 3 \mathrm{H}), 1.00(\mathrm{~s}, 3 \mathrm{H}), 0.97(\mathrm{~s}, 3 \mathrm{H}), 0.77(\mathrm{~s}, 3 \mathrm{H})$. ${ }^{13} \mathrm{C}$ NMR $\left(101 \mathrm{MHz}, \mathrm{CDCl}_{3}\right) \delta 181.3,150.2,148.1,147.2,141.8,137.9,130.1,119.9,109.8$, $108.3,107.2,101.1,56.4,54.5,52.6,50.8,49.2,49.2,46.9,42.4,40.5,38.9,38.5,38.3,37.0$, $33.7,33.3,32.0,30.5,29.8,28.7,25.4,21.3,21.3,19.4,18.9,16.0,15.7,14.6$. HRMS $\left(\mathrm{ESI}^{+}\right)$: $\mathrm{m} / \mathrm{z}$ calculated for $\mathrm{C}_{38} \mathrm{H}_{51} \mathrm{~N}_{3} \mathrm{O}_{4} \mathrm{H}[\mathrm{M}+\mathrm{H}]^{+}:$614.3952, found 614.3951 .

\section{1'-(Furan-2-ylmethyl)-1 $H^{\prime}$-lup-2-eno-[2,3-d]-[1,2,3]-triazole-28-oic acid (5k).}

Betulonic acid (100 mg, 1 equiv., $0.220 \mathrm{mmol}$ ), furfurylamine (28 mg, 1.3 equiv., $0.286 \mathrm{mmol}$ ), 4-nitrophenyl azide (36 mg, 1 equiv., $0.220 \mathrm{mmol}$ ), $4 \AA$ molecular sieves (50 mg) and toluene $(0.5 \mathrm{~mL})$. Reaction time is overnight. The product was purified by flash column chromatography (first washed with $\mathrm{CH}_{2} \mathrm{Cl}_{2}$ followed by petroleum ether : EtOAc 9:1 $\rightarrow 6: 4$ ) affording $\mathbf{5 k}$ (66 mg, $53 \%$ yield) as a brown crystals. m.p. $227^{\circ} \mathrm{C} .{ }^{1} \mathrm{H}$ NMR $\left(400 \mathrm{MHz}, \mathrm{CDCl}_{3}\right) \delta 7.35(\mathrm{~s}, 1 \mathrm{H}), 6.34-$ $6.31(\mathrm{~m}, 1 \mathrm{H}), 6.23(\mathrm{~d}, J=3.1 \mathrm{~Hz}, 1 \mathrm{H}), 5.55(\mathrm{~s}, 2 \mathrm{H}), 4.76(\mathrm{~s}, 1 \mathrm{H}), 4.64(\mathrm{~s}, 1 \mathrm{H}), 3.07-2.99(\mathrm{~m}$, 1H), $2.93(\mathrm{~d}, J=15.3 \mathrm{~Hz}, 1 \mathrm{H}), 2.30-2.11(\mathrm{~m}, 3 \mathrm{H}), 1.99(\mathrm{~d}, J=7.5 \mathrm{~Hz}, 2 \mathrm{H}), 1.78-1.66(\mathrm{~m}$, $5 \mathrm{H}), 1.60-1.40(\mathrm{~m}, 11 \mathrm{H}), 1.28(\mathrm{t}, J=10.2 \mathrm{~Hz}, 7 \mathrm{H}), 1.15(\mathrm{~s}, 3 \mathrm{H}), 1.00(\mathrm{~s}, 3 \mathrm{H}), 0.98(\mathrm{~s}, 3 \mathrm{H})$, 0.77 (s, 3H). ${ }^{13} \mathrm{C}$ NMR $\left(101 \mathrm{MHz}, \mathrm{CDCl}_{3}\right) \delta$ 179.9, 150.2, 148.8, 142.5, 141.6, 137.7, 110.7, 109.9, 109.0, 56.3, 54.6, 49.3, 49.2, 46.8, 46.4, 42.4, 40.6, 39.0, 38.4, 38.3, 37.0, 33.6, 33.3, $32.0,30.5,29.8,29.7,28.6,19.4,18.9,16.1,15.7,14.6$. HRMS $\left(E S I^{+}\right): m / z$ calculated for $\mathrm{C}_{35} \mathrm{H}_{49} \mathrm{~N}_{3} \mathrm{O}_{3} \mathrm{H}[\mathrm{M}+\mathrm{H}]^{+}: 560.3846$, found 560.3857 .

\section{1'-((1H-Indol-3-yl)methyl)-1H'-lup-2-eno-[2,3-d]-[1,2,3]-triazole-28-oic acid (5I).}

Betulonic acid (100 mg, 1 equiv., $0.220 \mathrm{mmol}$ ), tryptamine (46 mg, 1.3 equiv., $0.286 \mathrm{mmol}$ ), 4nitrophenyl azide (36 mg, 1 equiv., $0.220 \mathrm{mmol}$ ), $4 \AA$ molecular sieves (50 mg) and toluene $(0.5 \mathrm{~mL})$. Reaction time is overnight. The product was purified by flash column chromatography (first washed with $\mathrm{CH}_{2} \mathrm{Cl}_{2}$ followed by petroleum ether : EtOAc 9:1 $\rightarrow$ 6:4) affording $5 \mathrm{I}$ (115 mg, $84 \%$ yield) as off white crystals. m.p. $196{ }^{\circ} \mathrm{C} .{ }^{1} \mathrm{H}$ NMR (400 MHz, DMSO) $\delta 10.87(\mathrm{~s}, 1 \mathrm{H})$, 
$7.41(\mathrm{~d}, J=7.8 \mathrm{~Hz}, 1 \mathrm{H}), 7.33(\mathrm{~d}, J=8.1 \mathrm{~Hz}, 1 \mathrm{H}), 7.10-7.02(\mathrm{~m}, 2 \mathrm{H}), 6.96(\mathrm{~m}, 1 \mathrm{H}), 4.72(\mathrm{~s}$, 1H), $4.72(\mathrm{~s}, 1 \mathrm{H}), 4.59(\mathrm{~s}, 1 \mathrm{H}), 4.54(\mathrm{~s}, 2 \mathrm{H}), 3.17(\mathrm{~s}, 1 \mathrm{H}), 3.03-2.92(\mathrm{~m}, 1 \mathrm{H}), 2.70(\mathrm{~d}, J=15.2$ $\mathrm{Hz}, 1 \mathrm{H}), 2.29(\mathrm{~m}, 1 \mathrm{H}), 2.14-2.06(\mathrm{~m}, 2 \mathrm{H}), 1.81(\mathrm{~d}, J=6.9 \mathrm{~Hz}, 2 \mathrm{H}), 1.63(\mathrm{~d}, J=29.9 \mathrm{~Hz}, 5 \mathrm{H})$, $1.57-1.24(\mathrm{~m}, 11 \mathrm{H}), 1.25-1.01(\mathrm{~m}, 7 \mathrm{H}), 0.96(\mathrm{~s}, 3 \mathrm{H}), 0.93(\mathrm{~s}, 3 \mathrm{H}), 0.90(\mathrm{~s}, 3 \mathrm{H}), 0.63(\mathrm{~s}, 3 \mathrm{H})$. ${ }^{13} \mathrm{C}$ NMR $(101 \mathrm{MHz}$, DMSO) $\delta 177.7,150.7,140.3,137.8,136.5,127.4,123.7,121.4,118.9$, $118.3,111.8,110.7,110.1,55.9,54.4,50.1,49.0,48.9,47.0,42.5,38.8,38.1,36.7,33.5,33.3$, $32.0,31.1,30.5,29.7,28.6,26.9,25.5,21.4,21.1,19.4,18.8,16.1,15.7,14.8$. HRMS $\left(\mathrm{ESI}^{+}\right)$: $\mathrm{m} / \mathrm{z}$ calculated for $\mathrm{C}_{40} \mathrm{H}_{54} \mathrm{~N}_{4} \mathrm{O}_{2} \mathrm{H}[\mathrm{M}+\mathrm{H}]^{+}:$623.4319, found 623.4317 .

\section{1'-(2-(1H-Indol-3-yl)ethyl)-1H'-lup-2-eno-[2,3-d]-[1,2,3]-triazole-28-oic acid (5m).}

Betulonic acid (100 mg, 1 equiv., $0.220 \mathrm{mmol}$ ), 5-methoxytryptamine (54 mg, 1.3 equiv., 0.286 mmol), 4-nitrophenyl azide (36 mg, 1 equiv., $0.220 \mathrm{mmol}$ ), $4 \AA$ molecular sieves (50 mg) and toluene $(0.5 \mathrm{~mL})$. Reaction time is overnight. The product was purified by flash column chromatography (first washed with $\mathrm{CH}_{2} \mathrm{Cl}_{2}$ followed by petroleum ether : EtOAc 9:1 $\rightarrow$ 6:4 ) affording $5 \mathrm{~m}$ (126 mg, $88 \%$ yield) as off white crystals. m.p. $240{ }^{\circ} \mathrm{C} .{ }^{1} \mathrm{H}$ NMR $(400 \mathrm{MHz}, \mathrm{DMSO})$ $\delta 10.69(\mathrm{~s}, 1 \mathrm{H}), 7.19(\mathrm{~d}, J=8.7 \mathrm{~Hz}, 1 \mathrm{H}), 7.05(\mathrm{~s}, 1 \mathrm{H}), 6.76(\mathrm{~s}, 1 \mathrm{H}), 6.67(\mathrm{~d}, J=8.7 \mathrm{~Hz}, 1 \mathrm{H})$, $4.72(\mathrm{~s}, 1 \mathrm{H}), 4.59(\mathrm{~s}, 1 \mathrm{H}), 4.57-4.45(\mathrm{~m}, 2 \mathrm{H}), 3.71(\mathrm{~s}, 2 \mathrm{H}), 3.03-2.92(\mathrm{~m}, 1 \mathrm{H}), 2.69(\mathrm{~d}, J=$ $15.3 \mathrm{~Hz}, 1 \mathrm{H}), 2.28(\mathrm{~m}, 1 \mathrm{H}), 2.09(\mathrm{~m}, 2 \mathrm{H}), 1.81(\mathrm{~d}, J=6.9 \mathrm{~Hz}, 2 \mathrm{H}), 1.73-1.55(\mathrm{~m}, 5 \mathrm{H}), 1.32$ $(\mathrm{m}, 11 \mathrm{H}), 1.19-1.02(\mathrm{~m}, 7 \mathrm{H}), 0.96(\mathrm{~s}, 3 \mathrm{H}), 0.89(\mathrm{~s}, 3 \mathrm{H}), 0.86(\mathrm{~s}, 3 \mathrm{H}), 0.58(\mathrm{~s}, 3 \mathrm{H}) .{ }^{13} \mathrm{C}$ NMR (101 MHz, DMSO) $\delta 177.7,153.5,150.7,140.3,137.9,131.5,127.8,124.3,112.4,111.7$, $110.7,110.1,99.9,55.9,55.5,54.4,50.2,48.9,47.0,42.5,38.8,38.1,36.7,33.5,33.3,32.0$, $30.5,29.7,28.5,26.9,25.5,22.5,21.4,20.9,19.4,18.8,16.0,15.7,14.8$. HRMS $\left._{(E S I}\right):$ m/z calculated for $\mathrm{C}_{41} \mathrm{H}_{56} \mathrm{~N}_{4} \mathrm{O}_{3} \mathrm{H}[\mathrm{M}+\mathrm{H}]^{+}:$653.4424, found 653.4418 .

\section{1'-((1H-Indol-4-yl)methyl)-1H'-lup-2-eno-[2,3-d]-[1,2,3]-triazole-28-oic acid (5n).}

Betulonic acid (100 mg, 1 equiv., $0.220 \mathrm{mmol}$ ), 4-(aminomethyl) indole (42 mg, 1.3 equiv., $0.286 \mathrm{mmol}$ ), 4-nitrophenyl azide (36 mg, 1 equiv., $0.220 \mathrm{mmol}$ ), $4 \AA$ molecular sieves (50 mg) and toluene $(0.5 \mathrm{~mL})$. Reaction time is overnight. The product was purified by flash column 
chromatography (first washed with $\mathrm{CH}_{2} \mathrm{Cl}_{2}$ followed by petroleum ether : EtOAc 9:1 $\rightarrow$ 6:4 ) affording $5 \mathrm{n}$ (98 mg, $73 \%$ yield) as off white crystals. m.p. $260{ }^{\circ} \mathrm{C} .{ }^{1} \mathrm{H}$ NMR $\left(400 \mathrm{MHz}, \mathrm{CDCl}_{3}\right)$ $\delta 8.32(\mathrm{~s}, 1 \mathrm{H}), 7.31(\mathrm{~d}, J=8.2 \mathrm{~Hz}, 1 \mathrm{H}), 7.22(\mathrm{~m}, 1 \mathrm{H}), 7.07(\mathrm{~m}, 1 \mathrm{H}), 6.52-6.40(\mathrm{~m}, 2 \mathrm{H}), 5.93$ (m, 2H), $4.76(\mathrm{~s}, 1 \mathrm{H}), 4.65(\mathrm{~s}, 1 \mathrm{H}), 3.07-2.93(\mathrm{~m}, 2 \mathrm{H}), 2.31-2.16(\mathrm{~m}, 3 \mathrm{H}), 2.05-1.93(\mathrm{~m}$, 2H), $1.77-1.64(\mathrm{~m}, 5 \mathrm{H}), 1.59-1.35(\mathrm{~m}, 11 \mathrm{H}), 1.34-1.15(\mathrm{~m}, 7 \mathrm{H}), 1.12(\mathrm{~d}, \mathrm{~J}=14.6 \mathrm{~Hz}, 3 \mathrm{H})$, 0.99 (s, 3H), 0.96 (s, 3H), 0.78 (s, 3H). ${ }^{13} \mathrm{C}$ NMR (101 MHz, $\left.\mathrm{CDCl}_{3}\right) \delta$ 180.4, 150.2, 141.9, 138.3, 135.7, 128.2, 125.2, 124.5, 122.1, 117.5, 110.6, 109.8, 100.0, 56.3, 54.6, 51.4, 49.2, $49.2,46.9,42.4,40.5,38.9,37.0,33.8,33.3,32.0,30.5,29.7,29.7,28.4,25.5,22.7,21.3$, 20.9, 19.4, 18.9, 16.0, 15.6, 14.6. HRMS $\left(\mathrm{ESI}^{+}\right): \mathrm{m} / \mathrm{z}$ calculated for $\mathrm{C}_{39} \mathrm{H}_{52} \mathrm{~N}_{4} \mathrm{O}_{2} \mathrm{H}[\mathrm{M}+\mathrm{H}]^{+}$: 609.4162 , found 609.4174 .

\section{1'-(2-Hydroxyethyl)-1 $H^{\prime}$-lup-2-eno-[2,3-d]-[1,2,3]-triazole-28-oic acid (5o).}

Betulonic acid (100 mg, 1 equiv., $0.220 \mathrm{mmol}$ ), ethanolamine (17 mg, 1.3 equiv., $0.286 \mathrm{mmol}$ ), 4-nitrophenyl azide (36 mg, 1 equiv., $0.220 \mathrm{mmol}$ ), $4 \AA$ molecular sieves (50 mg) and toluene $(0.5 \mathrm{~mL})$. Reaction time is overnight. The product was purified by flash column chromatography (first washed with $\mathrm{CH}_{2} \mathrm{Cl}_{2}$ followed by $\mathrm{CH}_{2} \mathrm{Cl}_{2}$ : MeOH 95:5) affording 50 (70 mg, 62\% yield) as off white crystals. m.p. $236^{\circ} \mathrm{C} .{ }^{1} \mathrm{H}$ NMR $(400 \mathrm{MHz}$, DMSO) $\delta 4.72(\mathrm{~s}, 1 \mathrm{H}), 4.59(\mathrm{~s}, 1 \mathrm{H}), 4.36$ (m, 2H), $3.86(\mathrm{~m}, 2 \mathrm{H}), 2.98(\mathrm{~m}, 1 \mathrm{H}), 2.70(\mathrm{~d}, J=15.2 \mathrm{~Hz}, 1 \mathrm{H}), 2.30(\mathrm{~m}, 1 \mathrm{H}), 2.11(\mathrm{~m}, 2 \mathrm{H}), 1.82$ (d, J = 6.9 Hz, 2H), $1.64(\mathrm{~s}, \mathrm{br}, 5 \mathrm{H}), 1.58-1.33(\mathrm{~m}, 11 \mathrm{H}), 1.33-1.22(\mathrm{~m}, 7 \mathrm{H}), 1.17(\mathrm{~s}, 3 \mathrm{H})$,

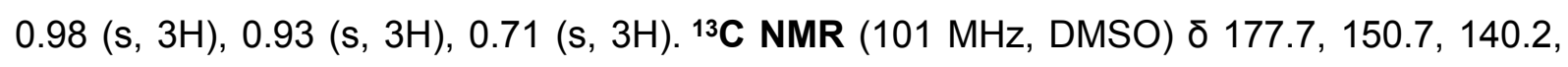
$138.0,110.1,79.6,60.7,55.9,54.5,51.4,48.9,47.0,42.5,38.9,38.1,36.7,33.6,33.3,32.0$, 30.5, 29.8, 28.7, 25.5, 21.4, 19.4, 18.8, 16.2, 15.8, 14.8. HRMS $\left(E S I^{+}\right): \mathrm{m} / \mathrm{z}$ calculated for $\mathrm{C}_{32} \mathrm{H}_{49} \mathrm{~N}_{3} \mathrm{O}_{3} \mathrm{H}[\mathrm{M}+\mathrm{H}]^{+}:$524.3846, found 524.3853.

\section{1'-Heptyl-1 $H^{\prime}$-lup-2-eno-[2,3-d]-[1,2,3]-triazole-28-oic acid (5p).}

Betulonic acid (100 mg, 1 equiv., $0.220 \mathrm{mmol}$ ), 1-heptylamine (33 mg, 1.3 equiv, $0.286 \mathrm{mmol}$ ), 4-nitrophenyl azide (36 mg, 1 equiv, $0.220 \mathrm{mmol}$ ), $4 \AA$ molecular sieves (50 mg) and toluene $(0.5 \mathrm{~mL})$. Reaction time is overnight. The product was purified by flash column chromatography 
(first washed with $\mathrm{CH}_{2} \mathrm{Cl}_{2}$ followed by petroleum ether : EtOAc 9:1 $\rightarrow$ 6:4 ) affording 5 p $(72 \mathrm{mg}$, $57 \%$ yield $)$ as off white crystals. m.p. $273{ }^{\circ} \mathrm{C} .{ }^{1} \mathrm{H}$ NMR $\left(600 \mathrm{MHz}, \mathrm{CDCl}_{3}\right) \delta 4.76(\mathrm{~s}, 1 \mathrm{H}), 4.64$ (s, 1H), $4.33-4.23(\mathrm{~m}, 2 \mathrm{H}), 3.04(\mathrm{~m}, 1 \mathrm{H}), 2.91(\mathrm{~d}, J=15.3 \mathrm{~Hz}, 1 \mathrm{H}), 2.33-2.22(\mathrm{~m}, 2 \mathrm{H}), 2.13$ $(\mathrm{d}, J=15.3 \mathrm{~Hz}, 1 \mathrm{H}), 2.00-1.96(\mathrm{~m}, 2 \mathrm{H}), 1.79-1.64(\mathrm{~m}, 5 \mathrm{H}), 1.61-1.35(\mathrm{~m}, 13 \mathrm{H}), 1.35-$ $1.19(\mathrm{~m}, 14 \mathrm{H}), 1.17(\mathrm{~s}, 3 \mathrm{H}), 1.00(\mathrm{~s}, 3 \mathrm{H}), 0.99(\mathrm{~s}, 3 \mathrm{H}), 0.88(\mathrm{~m}, 3 \mathrm{H}), 0.77(\mathrm{~s}, 3 \mathrm{H}) .{ }^{13} \mathrm{C} \mathrm{NMR}$ $\left(101 \mathrm{MHz}, \mathrm{CDCl}_{3}\right) \delta 181.7,150.2,141.0,137.3,109.8,56.4,54.6,49.6,49.2,49.2,46.9,42.4$ $40.5,38.9,38.5,38.2,37.0,33.6,33.3,32.1,31.6,30.8,30.6,29.8,29.7,28.8,28.6,26.9$, $25.4,22.5,21.3,19.4,18.9,16.0,15.7,14.6,14.0$. HRMS $\left(E S I^{+}\right): \mathrm{m} / \mathrm{z}$ calculated for $\mathrm{C}_{37} \mathrm{H}_{59} \mathrm{~N}_{3} \mathrm{O}_{2} \mathrm{H}[\mathrm{M}+\mathrm{H}]^{+}:$578.4679, found 578.4687 .

\section{$1 H^{\prime}$-Lup-2-eno-[2,3-d]-[1,2,3]-triazole-28-oic acid (5q).}

Betulonic acid (100 mg, 1 equiv., $0.220 \mathrm{mmol}$ ), ammonium acetate (85 mg, 5 equiv., 1.100 mmol), 4-nitrophenyl azide (51 mg, 1.4 equiv., $0.308 \mathrm{mmol}$ ), $80{ }^{\circ} \mathrm{C}, 4 \AA$ molecular sieves (50 $\mathrm{mg})$ and DMF $(0.8 \mathrm{~mL})$. Reaction time is overnight. The product was purified by flash column chromatography (first washed with $\mathrm{CH}_{2} \mathrm{Cl}_{2}$ followed by $\mathrm{CH}_{2} \mathrm{Cl}_{2}$ : MeOH 95:5) affording $5 \mathbf{q}$ (90 $\mathrm{mg}, 86 \%$ yield) as off white crystals. m.p. $158^{\circ} \mathrm{C}$. Spectroscopic data for compound $\mathbf{5 q}$ was consistent with previously reported data for this compound. ${ }^{27}{ }^{1} \mathrm{H}$ NMR $\left(400 \mathrm{MHz}, \mathrm{CDCl}_{3}\right) \delta 4.77$ (s, 1H), $4.64(\mathrm{~s}, 1 \mathrm{H}), 3.03(\mathrm{~d}, J=10.1 \mathrm{~Hz}, 1 \mathrm{H}), 2.90(\mathrm{~d}, J=15.5 \mathrm{~Hz}, 1 \mathrm{H}), 2.37-2.22(\mathrm{~m}, 2 \mathrm{H})$, $2.12(\mathrm{~d}, J=15.5 \mathrm{~Hz}, 1 \mathrm{H}), 2.00(\mathrm{dd}, J=19.9,11.7 \mathrm{~Hz}, 2 \mathrm{H}), 1.83-1.66(\mathrm{~m}, 5 \mathrm{H}), 1.57(\mathrm{dd}, J=$ 38.5, 24.6 Hz, 12H), $1.36-1.24(\mathrm{~m}, 7 \mathrm{H}), 1.21(\mathrm{~d}, J=7.0 \mathrm{~Hz}, 4 \mathrm{H}), 1.01(\mathrm{~s}, 3 \mathrm{H}), 1.00(\mathrm{~s}, 3 \mathrm{H})$ 0.78 (s, 3H). ${ }^{13} \mathrm{C}$ NMR $\left(101 \mathrm{MHz}, \mathrm{CDCl}_{3}\right) \delta 181.0,150.3,150.1,140.5,109.8,56.3,53.4,49.2$, $49.0,46.9,42.5,40.7,39.0,38.4,37.3,37.0,33.3,33.3,32.1,31.0,30.6,29.8,25.5,23.7$, 21.4, 19.4, 19.1, 16.2, 15.6, 14.6. HRMS $\left(\mathrm{ESI}^{+}\right): \mathrm{m} / \mathrm{z}$ calculated for $\mathrm{C}_{30} \mathrm{H}_{45} \mathrm{~N}_{3} \mathrm{O}_{2} \mathrm{H}[\mathrm{M}+\mathrm{H}]^{+}$: 480.3584 , found 480.3585 .

\section{1'-Benzyl-1H'-lup-2-eno-[2,3-d]-[1,2,3]-triazole-28-oic acid (5r).}

Betulonic acid (100 mg, 1 equiv., $0.220 \mathrm{mmol}$ ), benzylamine (31 mg, 1.3 equiv., $0.286 \mathrm{mmol}$ ), 
4-nitrophenyl azide (36 mg, 1 equiv., $0.220 \mathrm{mmol}$ ), $4 \AA$ molecular sieves (50 mg) and toluene $(0.5 \mathrm{~mL})$. Reaction time is overnight. The product was purified by flash column chromatography (first washed with $\mathrm{CH}_{2} \mathrm{Cl}_{2}$ followed by petroleum ether : EtOAc 9:1 $\rightarrow$ 6:4 ) affording $5 \mathbf{r}$ (115 $\mathrm{mg}, 92 \%$ yield) as off white crystals. m.p. $290{ }^{\circ} \mathrm{C} .{ }^{1} \mathrm{H}$ NMR $\left(400 \mathrm{MHz}, \mathrm{CDCl}_{3}\right) \delta 7.33-7.24(\mathrm{~m}$, 3H), $7.02(\mathrm{~d}, J=7.2 \mathrm{~Hz}, 2 \mathrm{H}), 5.64(\mathrm{~s}, 2 \mathrm{H}), 4.76(\mathrm{~s}, 1 \mathrm{H}), 4.64(\mathrm{~s}, 1 \mathrm{H}), 3.09-3.00(\mathrm{~m}, 1 \mathrm{H}), 2.96$ (d, $J=15.4 \mathrm{~Hz}, 1 \mathrm{H}), 2.33-2.13(\mathrm{~m}, 3 \mathrm{H}), 2.06-1.93(\mathrm{~m}, 2 \mathrm{H}), 1.82-1.63(\mathrm{~m}, 5 \mathrm{H}), 1.61-1.37$ $(\mathrm{m}, 11 \mathrm{H}), 1.27-1.15(\mathrm{~m}, 7 \mathrm{H}), 1.04(\mathrm{~s}, 3 \mathrm{H}), 0.99(\mathrm{~s}, 3 \mathrm{H}), 0.97(\mathrm{~s}, 3 \mathrm{H}), 0.77(\mathrm{~s}, 3 \mathrm{H}) .{ }^{13} \mathrm{C}$ NMR $\left(101 \mathrm{MHz}, \mathrm{CDCl}_{3}\right) \delta 181.5,150.2,141.8,138.0,136.4,128.7,127.7,126.3,109.8,56.4,54.5$, $52.8,49.2,49.1,46.9,42.4,40.5,38.9,38.5,38.3,37.0,33.7,33.3,32.0,30.5,29.7,28.7$, 25.4, 23.8, 21.3, 21.3, 19.4, 18.9, 16.0, 15.7, 14.6. HRMS $\left(\mathrm{ESI}^{+}\right): \mathrm{m} / \mathrm{z}$ calculated for $\mathrm{C}_{37} \mathrm{H}_{51} \mathrm{~N}_{3} \mathrm{O}_{2} \mathrm{H}[\mathrm{M}+\mathrm{H}]^{+}: 570.4053$, found 570.4064 .

\section{1'-((R)-1-Phenylethyl)-1 $H^{\prime}$-lup-2-eno-[2,3-d]-[1,2,3]-triazole-28-oic acid (5s).}

Betulonic acid (100 mg, 1 equiv., $0.220 \mathrm{mmol}$ ), (R)-(+)- $\alpha-$ methylbenzylamine (35 mg, 1.3 equiv., $0.286 \mathrm{mmol}$ ), 4-nitrophenyl azide (36 mg, 1 equiv., $0.220 \mathrm{mmol}$ ), $4 \AA$ molecular sieves $(50 \mathrm{mg})$ and toluene $(0.5 \mathrm{~mL})$. Reaction time is overnight. The product was purified by flash column chromatography (first washed with $\mathrm{CH}_{2} \mathrm{Cl}_{2}$ followed by petroleum ether : EtOAc 9:1 $\rightarrow$ 6:4 ) affording 5 s (88 mg, $69 \%$ yield) as off white crystals. m.p. $327^{\circ} \mathrm{C} .{ }^{1} \mathrm{H}$ NMR $(600 \mathrm{MHz}$, $\left.\mathrm{CDCl}_{3}\right) \delta 7.30-7.20(\mathrm{~m}, 3 \mathrm{H}), 7.15-7.10(\mathrm{~m}, 2 \mathrm{H}), 5.73(\mathrm{~m}, 1 \mathrm{H}), 4.75(\mathrm{~s}, \mathrm{br}, 1 \mathrm{H}), 4.64(\mathrm{~s}, \mathrm{br}$, 1H), $3.02(\mathrm{~m}, 1 \mathrm{H}), 2.95(\mathrm{~d}, J=15.4 \mathrm{~Hz}, 1 \mathrm{H}), 2.32-2.22(\mathrm{~m}, 2 \mathrm{H}), 2.17(\mathrm{~d}, J=15.4 \mathrm{~Hz}, 1 \mathrm{H})$, $2.05-1.95(\mathrm{~m}, 5 \mathrm{H}), 1.80-1.64(\mathrm{~m}, 5 \mathrm{H}), 1.64-1.39(\mathrm{~m}, 11 \mathrm{H}), 1.38-1.25(\mathrm{~m}, 7 \mathrm{H}), 1.00(\mathrm{~s}$, 3H), 0.99 (s, 3H), 0.96 (s, 3H) $0.72(\mathrm{~s}, 3 \mathrm{H}) .{ }^{13} \mathrm{C}$ NMR (101 MHz, $\left.\mathrm{CDCl}_{3}\right) \delta$ 181.5, 150.2, 141.7, $141.1,137.6,128.6,127.5,126.1$, 109.8, 59.1, 56.4, 54.8, 49.3, 49.1, 46.8, 42.4, 40.5, 38.8, $38.4,38.3,37.0,33.6,33.3,32.0,30.5,29.7,28.6,25.4,23.3,21.4,21.3,19.4,19.0,15.9$, 15.6, 14.6. HRMS $\left(E S I^{+}\right): \mathrm{m} / \mathrm{z}$ calculated for $\mathrm{C}_{38} \mathrm{H}_{53} \mathrm{~N}_{3} \mathrm{O}_{2} \mathrm{H}[\mathrm{M}+\mathrm{H}]^{+}: 584.4210$, found 584.4214 .

\section{1'-((S)-1-Phenylethyl)-1H'-lupano-[2,3-d]-[1,2,3]-triazole-28-oic acid (5t).}

Dihydrobetulonic acid (100 mg, 1 equiv., $0.219 \mathrm{mmol}$ ), (S)-(-)-a-methylbenzylamine (34 mg, 
1.3 equiv., $0.285 \mathrm{mmol}$ ), 4-nitrophenyl azide (36 mg, 1 equiv., $0.219 \mathrm{mmol}), 4 \AA$ molecular sieves $(50 \mathrm{mg})$ and toluene $(0.5 \mathrm{~mL})$. Reaction time is overnight. The product was purified by flash column chromatography (first washed with $\mathrm{CH}_{2} \mathrm{Cl}_{2}$ followed by petroleum ether : EtOAc 9:1 $\rightarrow 6: 4$ ) affording 5 t (115 mg, 90\% yield) as off white crystals. m.p. $173^{\circ} \mathrm{C} .{ }^{1} \mathbf{H}$ NMR (400 $\left.\mathrm{MHz}, \mathrm{CDCl}_{3}\right) \delta 7.33-7.27(\mathrm{~m}, 2 \mathrm{H}), 7.22(\mathrm{~m}, 3 \mathrm{H}), 5.73(\mathrm{~m}, 1 \mathrm{H}), 2.98(\mathrm{~d}, J=15.2 \mathrm{~Hz}, 1 \mathrm{H}), 2.32$ - $2.22(\mathrm{~m}, 3 \mathrm{H}), 2.17(\mathrm{~d}, J=15.3 \mathrm{~Hz}, 1 \mathrm{H}), 2.03(\mathrm{~m}, 3 \mathrm{H}), 1.96-1.63(\mathrm{~m}, 5 \mathrm{H}), 1.45(\mathrm{~m}, 11 \mathrm{H})$, $1.29-1.22(\mathrm{~m}, 7 \mathrm{H}), 1.10(\mathrm{~s}, 3 \mathrm{H}), 0.97(\mathrm{~m}, 6 \mathrm{H}), 0.87(\mathrm{~s}, 3 \mathrm{H}), 0.82(\mathrm{~s}, 3 \mathrm{H}), 0.77(\mathrm{~s}, 3 \mathrm{H}) .{ }^{13} \mathrm{C}$ NMR $\left(101 \mathrm{MHz}, \mathrm{CDCl}_{3}\right) \delta 181.5,141.7,141.0,137.5,128.6,127.5,126.2,59.2,56.8,54.7$, $49.1,48.7,44.1,42.6,40.6,38.8,38.3,38.3,37.4,33.8,33.4,31.9,29.8,29.7,28.8,26.8$, 23.7, 23.0, 22.7, 21.3, 21.3, 18.9, 16.2, 15.7, 14.7, 14.5. HRMS (ESI+): m/z calculated for $\mathrm{C}_{38} \mathrm{H}_{55} \mathrm{~N}_{3} \mathrm{O}_{2} \mathrm{H}[\mathrm{M}+\mathrm{H}]^{+}:$586.4366, found 586.4370.

\section{1'-((S)-1-Phenylethyl)-28-methyl-1H'-lup-2-eno-[2,3-d]-[1,2,3]-triazole (5u).}

Lupenone (100 mg, 1 equiv., $0.235 \mathrm{mmol}$; provided by Milan Urban), (S)-(-)- - methylbenzylamine (37 mg, 1.3 equiv., $0.306 \mathrm{mmol}$ ), 4-nitrophenyl azide (39 mg, 1 equiv., $0.235 \mathrm{mmol}), 4 \AA$ molecular sieves $(50 \mathrm{mg})$ and toluene $(0.5 \mathrm{~mL})$. Reaction time is overnight. The product was purified by flash column chromatography (first washed with $\mathrm{CH}_{2} \mathrm{Cl}_{2}$ followed by petroleum ether : EtOAc 9:1 $\rightarrow$ 6:4 ) affording $\mathbf{5 u}(107 \mathrm{mg}, 83 \%$ yield) as off white solid. m.p. $283^{\circ} \mathrm{C} .{ }^{1} \mathrm{H}$ NMR $\left(600 \mathrm{MHz}, \mathrm{CDCl}_{3}\right) \delta 7.29(\mathrm{t}, J=7.7 \mathrm{~Hz}, 2 \mathrm{H}), 7.23(\mathrm{t}, J=7.3 \mathrm{~Hz}, 1 \mathrm{H})$, $7.15(\mathrm{~d}, J=7.8 \mathrm{~Hz}, 2 \mathrm{H}), 5.75(\mathrm{~m}, 1 \mathrm{H}), 4.71(\mathrm{~s}, 1 \mathrm{H}), 4.60(\mathrm{~s}, 1 \mathrm{H}), 2.95(\mathrm{~d}, J=15.3 \mathrm{~Hz}, 1 \mathrm{H})$, $2.39(\mathrm{~m}, 1 \mathrm{H}), 2.17(\mathrm{~d}, J=15.4 \mathrm{~Hz}, 1 \mathrm{H}), 2.03(\mathrm{~d}, J=7.0 \mathrm{~Hz}, 3 \mathrm{H}), 1.93(\mathrm{~m}, 1 \mathrm{H}), 1.74-1.68(\mathrm{~m}$, $5 \mathrm{H}), 1.68-1.40(\mathrm{~m}, 11 \mathrm{H}), 1.40-1.27(\mathrm{~m}, 9 \mathrm{H}), 1.06(\mathrm{~s}, 3 \mathrm{H}), 0.98(\mathrm{~s}, 3 \mathrm{H}), 0.96(\mathrm{~s}, 3 \mathrm{H}), 0.80$ (s, 3H), 0.73 (s, 3H). ${ }^{13} \mathrm{C}$ NMR $\left(151 \mathrm{MHz}, \mathrm{CDCl}_{3}\right) \delta 150.7,141.9,141.2,137.6,128.6,127.5$, $126.1,109.5,77.2,77.0,76.8,59.1,54.9,49.2,48.2,47.9,43.0,42.8,40.7,39.9,38.8,38.5$, $38.2,35.5,33.6,33.3,29.8,28.6,27.5,25.1,23.4,21.5,19.3,19.0,18.0,15.9,15.6,14.5$. HRMS $\left(E S I^{+}\right):$m/z calculated for $\mathrm{C}_{38} \mathrm{H}_{55} \mathrm{~N}_{3} \mathrm{H}[\mathrm{M}+\mathrm{H}]^{+}:$: 554.4468 , found 554.4462 . 


\section{Biology}

\section{Anti-coronavirus evaluation in cell culture}

HCoV-229E was purchased from ATCC (VR-740) and expanded in human embryonic lung fibroblast cells (HEL; ATCC $\left.{ }^{\circledR} \mathrm{CCL}-137\right)$. The titers of virus stocks were determined in HEL cells and expressed as $\operatorname{TCID}_{50}\left(50 \%\right.$ tissue culture infective dose).${ }^{54}$ The cytopathic effect (CPE) reduction assay was performed in 96-well plates containing confluent HEL cell cultures, as previously described. ${ }^{55}$ Serial compound dilutions were added together with HCoV-229E at an $\mathrm{MOI}$ of 100 . In parallel, the compounds were added to a mock-infected plate to assess cytotoxicity. Besides the test compounds, two references were included, i.e. K22 [(Z)-N-[3-[4(4-bromophenyl)-4-hydroxypiperidin-1-yl]-3-oxo-1-phenylprop-1-en-2-yl]benzamide;47 from ChemDiv] and GS-441524 (the nucleoside form of remdesivir; from Carbosynth). After five days incubation at $35^{\circ} \mathrm{C}$, microscopy was performed to score virus-induced CPE. To next perform the colorimetric MTS cell viability assay, the reagent (CellTiter $96^{\circledR} \mathrm{AQ}_{\text {ueous }} \mathrm{MTS}$ Reagent from Promega) was added to the wells, and $24 \mathrm{~h}$ later, absorbance at $490 \mathrm{~nm}$ was measured in a plate reader. Antiviral activity was calculated from three independent experiments and expressed as $\mathrm{EC}_{50}$ or concentration showing $50 \%$ efficacy in the MTS or microscopic assay (see reference ${ }^{56}$ for calculation details). Cytotoxicity was expressed as $50 \%$ cytotoxic concentration $\left(\mathrm{CC}_{50}\right)$ in the MTS assay.

\section{Immunofluorescence detection of viral dsRNA}

Semiconfluent cultures of human bronchial epithelial 16HBE cells (a gift from P. Hoet, Leuven, Belgium) in 8-well chamber slides (Ibidi) were infected with HCoV-229E (MOI: 1000) in the presence of $12 \mu \mathrm{M}$ of $5 \mathrm{~h}$ or GS-441524. After $4 \mathrm{~h}$ incubation at $35^{\circ} \mathrm{C}$, the inoculum was removed, the compound was added again and the slides were further incubated. At $24 \mathrm{~h}$ p.i., the cells were subjected to immunostaining for dsRNA (all incubations at room temperature). After cell fixation with $3.7 \%$ formaldehyde in PBS for $15 \mathrm{~min}$, and permeabilization with $0.2 \%$ Triton X-100 in PBS for 10 min, unspecific binding sites were blocked with 1\% BSA in PBS for 
30 min. Next, $1 \mathrm{~h}$ incubation was done with mouse monoclonal anti-dsRNA antibody (J2, SCICONS English \& Scientific Consulting Kft; diluted 1:1000 in PBS with 1\% BSA,), followed by $1 \mathrm{~h}$ incubation with goat anti-mouse AlexaFluor488 (A21131, Invitrogen; 1:1000 in PBS with 1\% BSA). Cell nuclei were stained with DAPI (4',6-diamidino-2-phenylindole, Invitrogen) in PBS for 20 min at RT. Microscopic images were acquired using the Leica TCS SP5 confocal microscope (Leica Microsystems) with a HCX PL APO 63x (NA 1.2) water immersion objective. DAPI and AlexaFluor488 were detected with excitation lines at $405 \mathrm{~nm}$ (blue) and $488 \mathrm{~nm}$ (green), and emission lines of 410-480 nm (blue) and 495-565 nm (green).

\section{Time-of-addition assay}

Confluent HEL cells were infected with HCoV-229E (MOI: 100) in a 96-well plate, and the compounds [ $\mathbf{h}$, bafilomycin $\mathrm{A}_{1}$ (from Cayman) or K22] were added at $-0.5,0.5,2,4,6$ or $8 \mathrm{~h}$ post-infection (p.i.). At $16 \mathrm{~h}$ p.i., the supernatant was discarded and each well was washed twice with ice-cold PBS. The cells were lysed on ice for 10 min with $22 \mu \mathrm{L}$ lysis mix, consisting of lysis enhancer and resuspension buffer at a 1:10 ratio (both from the CellsDirect One-Step RT-qPCR kit; Invitrogen). Next, the lysates were incubated for 10 min at $75^{\circ} \mathrm{C}$ and treated with DNase (Invitrogen) to remove interfering cellular DNA. The number of viral RNA copies in each sample was determined by one-step RT-qPCR. Five $\mu \mathrm{L}$ lysate was transferred to a qPCR plate containing 9.75 $\mu \mathrm{L}$ of RT-qPCR mix (CellsDirect One-Step RT-qPCR) and 0.25 $\mu \mathrm{L}$ Superscript III RT/Platinum Taq enzyme, and HCoV-229E N-gene specific primers and probe. ${ }^{57}$ The RTqPCR protocol consisted of $15 \mathrm{~min}$ at $50^{\circ} \mathrm{C} ; 2 \mathrm{~min}$ at $95^{\circ} \mathrm{C}$; and 40 cycles of $15 \mathrm{~s}$ at $95^{\circ} \mathrm{C}$ and $45 \mathrm{~s}$ at $60^{\circ} \mathrm{C}$. An N-gene plasmid standard was included to allow absolute quantification of viral RNA genome copies. The data from two independent experiments were expressed as the number of viral RNA copies at $16 \mathrm{~h}$ p.i. relative to the virus control receiving no compound.

\section{Selection of resistant coronavirus mutants}

HEL cells were infected with HCoV-229E virus (MOI: 25) and 5 h was added at different 
concentrations. After five days incubation at $35^{\circ} \mathrm{C}$, the $\mathrm{CPE}$ was scored microscopically to estimate the $\mathrm{EC}_{50}$ value. From the highest compound concentration conditions showing virusinduced CPE, the supernatants plus cells were frozen at $-80^{\circ} \mathrm{C}$. These harvests were further passaged in HEL cells under gradually increasing compound concentrations, until a manifest increase in $\mathrm{EC}_{50}$ was observed. A no compound control condition was passaged in parallel. The final virus passages were submitted to RNA extraction; reverse transcription; high-fidelity PCR; and cycle sequencing on the entire viral genome using a set of 39 primers (sequences available upon request). After sequence assembly with CLC Main Workbench 7.9.1 (Qiagen), the sequences of the viruses passaged in the absence and presence of $\mathbf{5 h}$ were aligned in order to identify the $\mathbf{5 h}$ resistance sites in the HCoV-229E genome.

\section{Virus yield assay}

The virus yield assay was performed in 96-well plates with semiconfluent cultures of $16 \mathrm{HBE}$ cells or confluent HEL cells. Serial dilutions of compound $\mathbf{5 h}$ were added and the cells were infected (MOI: 100) with wild-type HCoV-229E (229E-WT), EndoU-deficient HCoV-229E $\left(229 \mathrm{E}-\mathrm{H} 250 \mathrm{~A}_{\mathrm{nsp} 15}\right)^{26}$ or the mutant viruses obtained by passaging under $\mathbf{5 h}\left(229 \mathrm{E}-\mathrm{K} 60 \mathrm{R}_{\mathrm{nsp} 15}\right.$ or $\left.229 \mathrm{E}-\mathrm{T} 66 \mathrm{I}_{\mathrm{nsp} 15}\right)$. After $4 \mathrm{~h}$ incubation at $35^{\circ} \mathrm{C}$, the inoculum was removed, the compound dilutions were added again and the plates were further incubated. At three days p.i., the supernatants were collected, and $2 \mu \mathrm{L}$ of each supernatant was lysed on ice by adding $11 \mu \mathrm{L}$ lysis mix containing lysis enhancer and resuspension buffer at a 1:10 ratio. The lysates were incubated for $10 \mathrm{~min}$ at $75^{\circ} \mathrm{C}$ and the viral RNA copy number was determined by RT-qPCR as described above for the time-of-addition assay. The data were collected in three independent experiments and expressed as the fold reduction in viral RNA compared to the virus control receiving no compound.

\section{Computational work}


Starting from the published X-ray structure of hexameric nsp15 protein from HCoV-229E (PDB code: 4RS4), we first changed a few amino acid residues, i.e. S1Q, S17G, A142T, M219I and $\mathrm{S} 252 \mathrm{~L}$, to obtain the fully correct nsp15 protein sequence of HCoV-229E virus. The structures of HCoV-229E nsp15 and SARS-CoV-2 nsp 15 (PDB code: 7K1O) were prepared using MOE (Chemical Computing Group, Montreal, Canada). Hydrogen addition and optimization of protonation state and rotamers of the mutations were conducted using the AMBER-EHT force field, and identification of the potential binding sites in the multimeric complex was performed using MOE. Docking of betulonic acid derivatives was carried out by means of both MOE and GOLD with default settings, where GBVI/WSA score and Goldscore functions were used, respectively. The common top scoring solution was selected for further research. 


\section{ANCILLARY INFORMATION}

\section{SUPPORTING INFORMATION}

Figure S1: alignment of nsp15 protein sequences; HPLC traces of key compounds; and ${ }^{1} \mathrm{H}$ NMR and ${ }^{13} \mathrm{C}$ NMR spectra of the synthesized compounds (PDF).

Molecular Formula Strings (CSV).

PDB Coordinates for Computational Models: $5 \mathbf{h}$ in complex with nsp15 from HCoV-229E (PDB) and SARS-CoV-2 (PDB).

\section{CORRESPONDING AUTHOR INFORMATION}

E-mail: lieve.naesens@kuleuven.be. Phone: (+32)16322098.

*E-mail: besir.krasniqi@kuleuven.be. Phone: (+32)496798402.

\section{CURRENT AUTHOR ADDRESS}

Joice Thomas, Arcus Biosciences, Hayward, CA 94545, United States.

\section{AUTHOR INFORMATION}

The authors declare no conflict of interest.

\section{AUTHOR CONTRIBUTIONS}

A.S. and B.K. contributed equally. A.S. and L.N. designed, performed and interpreted the biological experiments. B.K. and J.T. performed compound synthesis and analysis. B.V.L., J.V. and D.J. performed antiviral experiments. T.N. and A.V. performed and interpreted the in silico study. V.T. and R.D. provided materials. A.S., B.K., W.D., A.V. and L.N. co-wrote the manuscript. All authors gave approval to the final version of the manuscript. 


\title{
ACKNOWLEDGMENT
}

B.K. acknowledges receipt of an Erasmus Mundus Western Balkan Action 2 and doctoral fellowship from KU Leuven. B.V.L. holds an SB-PhD fellowship from the FWO Research Foundation Flanders (project: 1S66321N). Mass spectrometry was made possible by the support of the Hercules Foundation of the Flemish Government (grant: 20100225-7). We acknowledge the support of NVIDIA Corporation for donating the Titan Xp GPU used for this study. This research work was supported by funding from the KU Leuven (IDO/12/020 and project C14/19/78); the European Union's Innovative Medicines Initiative (IMI) under Grant Agreement 101005077 [Corona Accelerated R\&D in Europe (CARE) project]; and Fundació La Marató de TV3, Spain (Project No. 201832-30). We thank Amy Swinnen and Leentje Persoons for dedicated technical assistance, and Els Vanstreels for providing confocal microscopy training. We also thank Milan Urban for providing lupenone.

\begin{abstract}
ABBREVIATIONS USED
$\mathrm{CC}_{50}, 50 \%$ cytotoxic concentration; CoV, coronavirus; COVID-19, coronavirus disease 2019; CPE, cytopathic effect; DAPI, 4',6-diamidino-2-phenylindole; EndoU, endoribonuclease; FIPV, feline infectious peritonitis virus; HEL, human embryonic lung; MERS, Middle East respiratory syndrome; MHV-A59, mouse hepatitis virus A59; MTS, 3-(4,5-dimethylthiazol-2-yl)-5-(3carboxymethoxyphenyl)-2-(4-sulfophenyl)-2H-tetrazolium; nsp, non-structural protein; p.i., post-infection; RTC, replication-transcription complex; SARS, severe acute respiratory syndrome; SARS-CoV-2, severe acute respiratory syndrome coronavirus 2; $\operatorname{TCID}_{50}, 50 \%$ tissue culture infective dose.
\end{abstract}

\section{REFERENCES}


1. Su, S.; Wong, G.; Shi, W.; Liu, J.; Lai, A. C.; Zhou, J.; Liu, W.; Bi, Y.; Gao, G. F., Epidemiology, genetic recombination, and pathogenesis of coronaviruses. Trends Microbiol. 2016, 24, 490-502.

2. Walsh, E. E.; Shin, J. H.; Falsey, A. R., Clinical impact of human coronaviruses $229 \mathrm{E}$ and OC43 infection in diverse adult populations. J. Infect. Dis. 2013, 208, 1634-1642.

3. Dijkman, R.; van der Hoek, L., Human coronaviruses 229E and NL63: close yet still so far. J. Formos. Med. Assoc. 2009, 108, 270-279.

4. Wang, C.; Horby, P. W.; Hayden, F. G.; Gao, G. F., A novel coronavirus outbreak of global health concern. Lancet 2020, 395, 470-473.

5. Fehr, A. R.; Perlman, S., Coronaviruses: an overview of their replication and pathogenesis. Methods Mol. Biol. 2015, 1282, 1-23.

6. Felsenstein, S.; Hedrich, C. M., SARS-CoV-2 infections in children and young people. Clin. Immunol. 2020, 220, 108588.

7. Amigues, I.; Pearlman, A. H.; Patel, A.; Reid, P.; Robinson, P. C.; Sinha, R.; Kim, A. H.; Youngstein, T.; Jayatilleke, A.; Konig, M., Coronavirus disease 2019: investigational therapies in the prevention and treatment of hyperinflammation. Expert Rev. Clin. Immunol. 2020, 16, 1185-1204.

8. Recovery Collaborative Group; Horby, P.; Lim, W. S.; Emberson, J. R.; Mafham, M.; Bell, J. L.; Linsell, L.; Staplin, N.; Brightling, C.; Ustianowski, A.; Elmahi, E.; Prudon, B.; Green, C.; Felton, T.; Chadwick, D.; Rege, K.; Fegan, C.; Chappell, L. C.; Faust, S. N.; Jaki, T.; Jeffery, K.; Montgomery, A.; Rowan, K.; Juszczak, E.; Baillie, J. K.; Haynes, R.; Landray, M. J., Dexamethasone in hospitalized patients with COVID-19 Preliminary report. N. Engl. J. Med. 2020, 384, 693-704.

9. Gil, C.; Ginex, T.; Maestro, I.; Nozal, V.; Barrado-Gil, L.; Cuesta-Geijo, M.; Urquiza, J.; Ramírez, D.; Alonso, C.; Campillo, N. E.; Martinez, A., COVID-19: drug targets and potential treatments. J. Med. Chem. 2020, 63, 12359-12386.

10. DeFrancesco, L., COVID-19 antibodies on trial. Nat. Biotechnol. 2020, 38, 1242-1252. 
11. Goldman, J. D.; Lye, D. C. B.; Hui, D. S.; Marks, K. M.; Bruno, R.; Montejano, R.; Spinner, C. D.; Galli, M.; Ahn, M. Y.; Nahass, R. G.; Chen, Y. S.; SenGupta, D.; Hyland, R. H.; Osinusi, A. O.; Cao, H.; Blair, C.; Wei, X.; Gaggar, A.; Brainard, D. M.; Towner, W. J.; Munoz, J.; Mullane, K. M.; Marty, F. M.; Tashima, K. T.; Diaz, G.; Subramanian, A.; GS-US-540-5773 Investigators, Remdesivir for 5 or 10 days in patients with severe Covid-19. N. Engl. J. Med. 2020, 383, 1827-1837.

12. Yin, W.; Mao, C.; Luan, X.; Shen, D. D.; Shen, Q.; Su, H.; Wang, X.; Zhou, F.; Zhao, W.; Gao, M.; Chang, S.; Xie, Y. C.; Tian, G.; Jiang, H. W.; Tao, S. C.; Shen, J.; Jiang, Y.; Jiang, H.; Xu, Y.; Zhang, S.; Zhang, Y.; Xu, H. E., Structural basis for inhibition of the RNA-dependent RNA polymerase from SARS-CoV-2 by remdesivir. Science 2020, $368,1499-1504$.

13. Sheahan, T. P.; Sims, A. C.; Graham, R. L.; Menachery, V. D.; Gralinski, L. E.; Case, J. B.; Leist, S. R.; Pyrc, K.; Feng, J. Y.; Trantcheva, I.; Bannister, R.; Park, Y.; Babusis, D.; Clarke, M. O.; Mackman, R. L.; Spahn, J. E.; Palmiotti, C. A.; Siegel, D.; Ray, A. S.; Cihlar, T.; Jordan, R.; Denison, M. R.; Baric, R. S., Broad-spectrum antiviral GS-5734 inhibits both epidemic and zoonotic coronaviruses. Sci. Transl. Med. 2017, 9, eaal3653.

14. Brown, A. J.; Won, J. J.; Graham, R. L.; Dinnon, K. H., 3rd; Sims, A. C.; Feng, J. Y.; Cihlar, T.; Denison, M. R.; Baric, R. S.; Sheahan, T. P., Broad spectrum antiviral remdesivir inhibits human endemic and zoonotic deltacoronaviruses with a highly divergent RNA dependent RNA polymerase. Antiviral Res. 2019, 169, 104541.

15. Kim, Y.; Lovell, S.; Tiew, K. C.; Mandadapu, S. R.; Alliston, K. R.; Battaile, K. P.; Groutas, W. C.; Chang, K. O., Broad-spectrum antivirals against 3C or 3C-like proteases of picornaviruses, noroviruses, and coronaviruses. J. Virol. 2012, 86, 1175411762.

16. Vuong, W.; Khan, M. B.; Fischer, C.; Arutyunova, E.; Lamer, T.; Shields, J.; Saffran, H. A.; McKay, R. T.; van Belkum, M. J.; Joyce, M. A.; Young, H. S.; Tyrrell, D. L.; Vederas, J. C.; Lemieux, M. J., Feline coronavirus drug inhibits the main protease of SARS-CoV- 
2 and blocks virus replication. Nat. Commun. 2020, 11, 4282. doi: 10.1038/s41467020-18096-2.

17. Fu, L.; Ye, F.; Feng, Y.; Yu, F.; Wang, Q.; Wu, Y.; Zhao, C.; Sun, H.; Huang, B.; Niu, P.; Song, H.; Shi, Y.; Li, X.; Tan, W.; Qi, J.; Gao, G. F., Both Boceprevir and GC376 efficaciously inhibit SARS-CoV-2 by targeting its main protease. Nat. Commun. 2020, $11,4417$.

18. Ricagno, S.; Egloff, M. P.; Ulferts, R.; Coutard, B.; Nurizzo, D.; Campanacci, V.; Cambillau, C.; Ziebuhr, J.; Canard, B., Crystal structure and mechanistic determinants of SARS coronavirus nonstructural protein 15 define an endoribonuclease family. Proc. Natl. Acad. Sci. USA 2006, 103, 11892-11897.

19. Huo, T.; Liu, X., Crystallization and preliminary X-ray crystallographic analysis of a nonstructural protein 15 mutant from Human coronavirus 229E. Acta Crystallogr. Sect. F Struct. Biol. Cryst. Commun. 2015, 71, 1156-1160.

20. Kim, Y.; Jedrzejczak, R.; Maltseva, N. I.; Wilamowski, M.; Endres, M.; Godzik, A.; Michalska, K.; Joachimiak, A., Crystal structure of Nsp15 endoribonuclease NendoU from SARS-CoV-2. Protein Sci. 2020, 29, 1596-1605.

21. Xu, X.; Zhai, Y.; Sun, F.; Lou, Z.; Su, D.; Xu, Y.; Zhang, R.; Joachimiak, A.; Zhang, X. C.; Bartlam, M.; Rao, Z., New antiviral target revealed by the hexameric structure of mouse hepatitis virus nonstructural protein nsp15. J. Virol. 2006, 80, 7909-7917.

22. Zhang, L.; Li, L.; Yan, L.; Ming, Z.; Jia, Z.; Lou, Z.; Rao, Z., Structural and biochemical characterization of endoribonuclease Nsp15 encoded by Middle East Respiratory Syndrome Coronavirus. J. Virol. 2018, 92, e00893-e00918.

23. Sevajol, M.; Subissi, L.; Decroly, E.; Canard, B.; Imbert, I., Insights into RNA synthesis, capping, and proofreading mechanisms of SARS-coronavirus. Virus Res. 2014, 194, 90-99.

24. V'Kovski, P.; Kratzel, A.; Steiner, S.; Stalder, H.; Thiel, V., Coronavirus biology and replication: implications for SARS-CoV-2. Nat. Rev. Microbiol. 2021, 19, 155-170. 
25. Deng, X.; Hackbart, M.; Mettelman, R. C.; O'Brien, A.; Mielech, A. M.; Yi, G.; Kao, C. C.; Baker, S. C., Coronavirus nonstructural protein 15 mediates evasion of dsRNA sensors and limits apoptosis in macrophages. Proc. Natl. Acad. Sci. U. S. A. 2017, 114, E4251-E4260.

26. Kindler, E.; Gil-Cruz, C.; Spanier, J.; Li, Y.; Wilhelm, J.; Rabouw, H. H.; Zust, R.; Hwang, M.; V'Kovski, P.; Stalder, H.; Marti, S.; Habjan, M.; Cervantes-Barragan, L.; Elliot, R.; Karl, N.; Gaughan, C.; van Kuppeveld, F. J.; Silverman, R. H.; Keller, M.; Ludewig, B.; Bergmann, C. C.; Ziebuhr, J.; Weiss, S. R.; Kalinke, U.; Thiel, V., Early endonuclease-mediated evasion of RNA sensing ensures efficient coronavirus replication. PLoS Pathog. 2017, 13, e1006195.

27. Hackbart, M.; Deng, X.; Baker, S. C., Coronavirus endoribonuclease targets viral polyuridine sequences to evade activating host sensors. Proc. Natl. Acad. Sci. USA 2020, 117, 8094-8103.

28. Ancar, R.; Li, Y.; Kindler, E.; Cooper, D. A.; Ransom, M.; Thiel, V.; Weiss, S. R.; Hesselberth, J. R.; Barton, D. J., Physiologic RNA targets and refined sequence specificity of coronavirus EndoU. RNA 2020, 26, 1976-1999.

29. Deng, X.; Baker, S. C., An "Old" protein with a new story: Coronavirus endoribonuclease is important for evading host antiviral defenses. Virology 2018, 517, 157-163.

30. Yuen, C. K.; Lam, J. Y.; Wong, W. M.; Mak, L. F.; Wang, X.; Chu, H.; Cai, J. P.; Jin, D. Y.; To, K. K.; Chan, J. F.; Yuen, K. Y.; Kok, K. H., SARS-CoV-2 nsp13, nsp14, nsp15 and orf6 function as potent interferon antagonists. Emerging Microbes Infect. 2020, 9, $1418-1428$.

31. Song, Z.; Mansbach, R. A.; He, H.; Shih, K. C.; Baumgartner, R.; Zheng, N.; Ba, X.; Huang, Y.; Mani, D.; Liu, Y.; Lin, Y.; Nieh, M. P.; Ferguson, A. L.; Yin, L.; Cheng, J., Modulation of polypeptide conformation through donor-acceptor transformation of sidechain hydrogen bonding ligands. Nat. Commun. 2017, 8, 92. 
32. Bonandi, E.; Christodoulou, M. S.; Fumagalli, G.; Perdicchia, D.; Rastelli, G.; Passarella, D., The 1,2,3-triazole ring as a bioisostere in medicinal chemistry. Drug Discov. Today 2017, 22, 1572-1581.

33. Mohammed, I.; Kummetha, I. R.; Singh, G.; Sharova, N.; Lichinchi, G.; Dang, J.; Stevenson, M.; Rana, T. M., 1,2,3-Triazoles as amide bioisosteres: discovery of a new class of potent HIV-1 Vif antagonists. J. Med. Chem. 2016, 59, 7677-7682.

34. Rani, A.; Singh, G.; Singh, A.; Maqbool, U.; Kaur, G.; Singh, J., CuAAC-ensembled 1,2,3-triazole-linked isosteres as pharmacophores in drug discovery: review. RSC Advances 2020, 10, 5610-5635.

35. Csuk, R., Betulinic acid and its derivatives: a patent review (2008-2013). Expert Opin. Ther. Pat. 2014, 24, 913-923.

36. Sidova, V.; Zoufaly, P.; Pokorny, J.; Dzubak, P.; Hajduch, M.; Popa, I.; Urban, M., Cytotoxic conjugates of betulinic acid and substituted triazoles prepared by Huisgen Cycloaddition from 30-azidoderivatives. PLoS One 2017, 12, e0171621.

37. Urban, M.; Sarek, J.; Klinot, J.; Korinkova, G.; Hajduch, M., Synthesis of A-seco derivatives of betulinic acid with cytotoxic activity. J. Nat. Prod. 2004, 67, 1100-1105.

38. Smith, P. F.; Ogundele, A.; Forrest, A.; Wilton, J.; Salzwedel, K.; Doto, J.; Allaway, G. P.; Martin, D. E., Phase I and II study of the safety, virologic effect, and pharmacokinetics/pharmacodynamics of single-dose 3-o-(3',3'dimethylsuccinyl)betulinic acid (bevirimat) against human immunodeficiency virus infection. Antimicrob. Agents Chemother. 2007, 51, 3574-3581.

39. Regueiro-Ren, A.; Dicker, I. B.; Hanumegowda, U.; Meanwell, N. A., Second generation inhibitors of HIV-1 maturation. ACS Med. Chem. Lett. 2019, 10, 287-294.

40. Thomas, J.; Jana, S.; John, J.; Liekens, S.; Dehaen, W., A general metal-free route towards the synthesis of 1,2,3-triazoles from readily available primary amines and ketones. Chem. Commun. 2016, 52, 2885-2888. 
41. Opsomer, T.; Thomas, J.; Dehaen, W., Chemoselectivity in the synthesis of 1,2,3triazoles from enolizable ketones, primary alkylamines, and 4-nitrophenyl azide. Synthesis 2017, 49, 4191-4198.

42. Silveira-Dorta, G.; Jana, S.; Borkova, L.; Thomas, J.; Dehaen, W., Straightforward synthesis of enantiomerically pure 1,2,3-triazoles derived from amino esters. Org. Biomol. Chem. 2018, 16, 3168-3176.

43. Flekhter, O. B.; Nigmatullina, L. R.; Baltina, L. A.; Karachurina, L. T.; Galin, F. Z.; Zarudii, F. S.; Tolstikov, G. A.; Boreko, E. I.; Pavlova, N. I.; Nikolaeva, S. N.; Savinova, O. V., Synthesis of betulinic acid from betulin extract and study of the antiviral and antiulcer activity of some related terpenoids. Pharm. Chem. J. 2002, 36, 484-487.

44. Dehelean, C. A.; Soica, C.; Ledeţi, I.; Aluaş, M.; Zupko, I.; G Luşcan, A.; Cinta-Pinzaru, S.; Munteanu, M., Study of the betulin enriched birch bark extracts effects on human carcinoma cells and ear inflammation. Chem. Cent. J. 2012, 6, 137.

45. Ressmann, A. K.; Kremsmayr, T.; Gaertner, P.; Zirbs, R.; Bica, K., Toward a benign strategy for the manufacturing of betulinic acid. Green Chem. 2017, 19, 1014-1022.

46. Šiman, P.; Filipová, A.; Tichá, A.; Niang, M.; Bezrouk, A.; Havelek, R., Effective method of purification of betulin from birch bark: the importance of its purity for scientific and medicinal use. PLoS One 2016, 11, e0154933.

47. Lundin, A.; Dijkman, R.; Bergstrom, T.; Kann, N.; Adamiak, B.; Hannoun, C.; Kindler, E.; Jonsdottir, H. R.; Muth, D.; Kint, J.; Forlenza, M.; Muller, M. A.; Drosten, C.; Thiel, V.; Trybala, E., Targeting membrane-bound viral RNA synthesis reveals potent inhibition of diverse coronaviruses including the Middle East respiratory syndrome virus. PLoS Pathog. 2014, 10, e1004166.

48. Chan, J. F.; Lau, S. K.; To, K. K.; Cheng, V. C.; Woo, P. C.; Yuen, K. Y., Middle East respiratory syndrome coronavirus: another zoonotic betacoronavirus causing SARSlike disease. Clin. Microbiol. Rev. 2015, 28, 465-522.

49. Chen, L.; Liu, W.; Zhang, Q.; Xu, K.; Ye, G.; Wu, W.; Sun, Z.; Liu, F.; Wu, K.; Zhong, B.; Mei, Y.; Zhang, W.; Chen, Y.; Li, Y.; Shi, M.; Lan, K.; Liu, Y., RNA based mNGS 
approach identifies a novel human coronavirus from two individual pneumonia cases in 2019 Wuhan outbreak. Emerging Microbes Infect. 2020, 9, 313-319.

50. Baggen, J.; Persoons, L.; Vanstreels, E.; Jansen, S.; Van Looveren, D.; Boeckx, B.; Geudens, V.; De Man, J.; Jochmans, D.; Wauters, J.; Wauters, E.; Vanaudenaerde, B. M.; Lambrechts, D.; Neyts, J.; Dallmeier, K.; Thibaut, H. J.; Jacquemyn, M.; Maes, P.; Daelemans, D., Genome-wide CRISPR screening identifies TMEM106B as a proviral host factor for SARS-CoV-2. Nat. Genet. 2021. doi: 10.1038/s41588-021-00805-2.

51. Bhardwaj, K.; Palaninathan, S.; Alcantara, J. M.; Yi, L. L.; Guarino, L.; Sacchettini, J. C.; Kao, C. C., Structural and functional analyses of the severe acute respiratory syndrome coronavirus endoribonuclease Nsp15. J. Biol. Chem. 2008, 283, 3655-3664.

52. Joseph, J. S.; Saikatendu, K. S.; Subramanian, V.; Neuman, B. W.; Buchmeier, M. J.; Stevens, R. C.; Kuhn, P., Crystal structure of a monomeric form of severe acute respiratory syndrome coronavirus endonuclease nsp15 suggests a role for hexamerization as an allosteric switch. J. Virol. 2007, 81, 6700-6708.

53. Genet, C.; Schmidt, C.; Strehle, A.; Schoonjans, K.; Auwerx, J.; Saladin, R.; Wagner, A., Redefining the TGR5 triterpenoid binding pocket at the C-3 position. ChemMedChem 2010, 5, 1983-1988.

54. Reed, L. J.; Muench, H., A simple method of estimating fifty per cent endpoints. Am. J. Epidemiol. 1938, 27, 493-497.

55. Apaydin, C. B.; Cesur, N.; Stevaert, A.; Naesens, L.; Cesur, Z., Synthesis and anticoronavirus activity of a series of 1-thia-4-azaspiro[4.5]decan-3-one derivatives. Arch. Pharm. (Weinheim) 2019, 352, e1800330.

56. Vrijens, P.; Noppen, S.; Boogaerts, T.; Vanstreels, E.; Ronca, R.; Chiodelli, P.; Laporte, M.; Vanderlinden, E.; Liekens, S.; Stevaert, A.; Naesens, L., Influenza virus entry via the GM3 ganglioside-mediated platelet-derived growth factor receptor beta signalling pathway. J. Gen. Virol. 2019, 100, 583-601. 
57. Szűcs, Z.; Naesens, L.; Stevaert, A.; Ostorházi, E.; Batta, G.; Herczegh, P.; Borbás, A., Reprogramming of the antibacterial drug vancomycin results in potent antiviral agents devoid of antibacterial activity. Pharmaceuticals (Basel) 2020, 13, 139. 


\section{TABLE OF CONTENTS GRAPHIC}

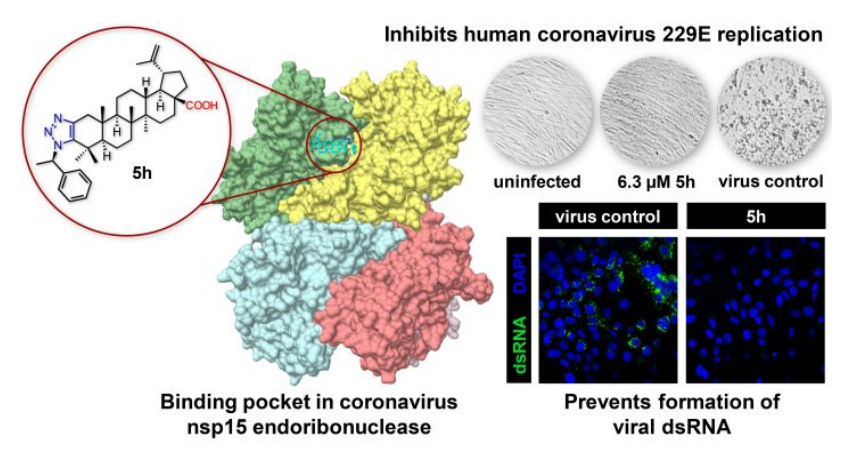


A
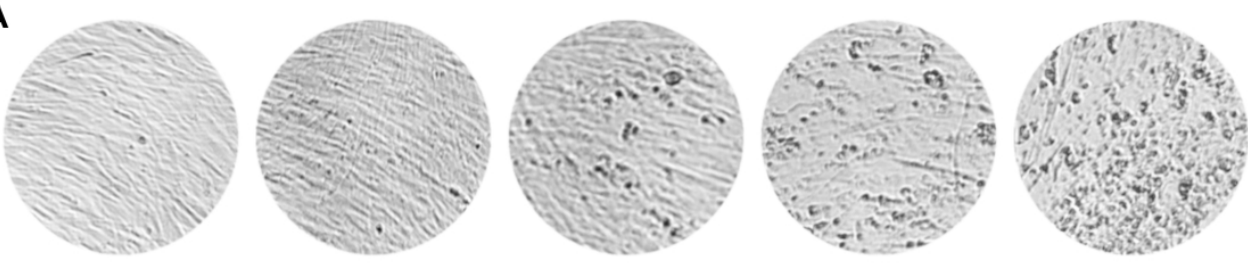

uninfected

$6.3 \mu \mathrm{M} 5 \mathrm{~h}$

$1.6 \mu \mathrm{M} 5 \mathrm{~h}$

$0.39 \mu \mathrm{M} 5 \mathrm{~h}$

virus control

B

C

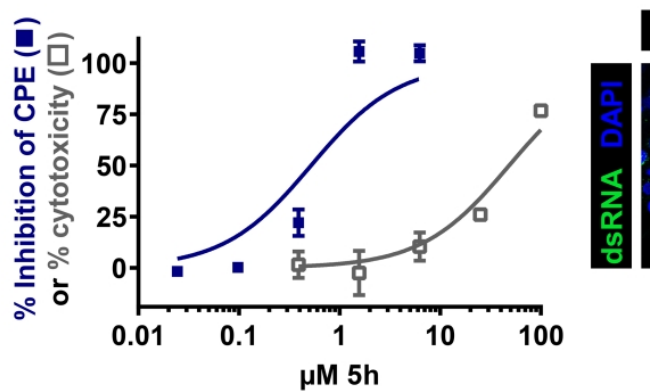

\begin{abstract}
virus control
\end{abstract}
$5 \mathbf{h}$

GS-441524
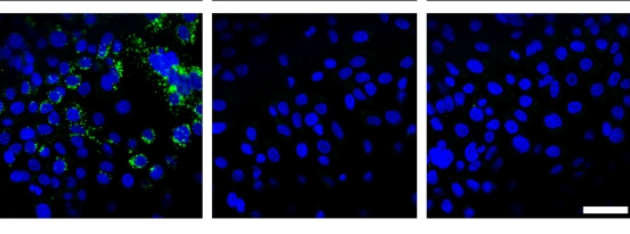

Figure 1. Activity of $\mathbf{5 h}$ against HCoV-229E. (A) Representative microscopic images showing protection against virus-induced cytopathic effect (CPE) in human embryonic lung (HEL) cells. (B) Dose-response curves for inhibition of virus-induced CPE ( $\mathbf{})$ and for cytotoxicity ( $\square$ ) in HEL cells, both determined by MTS cell viability assay. Data points are the mean \pm SEM $(N=3)$. (C) Immunofluorescence detection of viral dsRNA in HCoV-229E-infected human bronchial epithelial $16 \mathrm{HBE}$ cells at $24 \mathrm{~h}$ post-infection (p.i.). In green: dsRNA and in blue: nuclear DAPI staining. Compounds: $12 \mu \mathrm{M}$ 5h or $12 \mu \mathrm{M}$ GS-441524. Scale bar: $50 \mu \mathrm{m}$. 


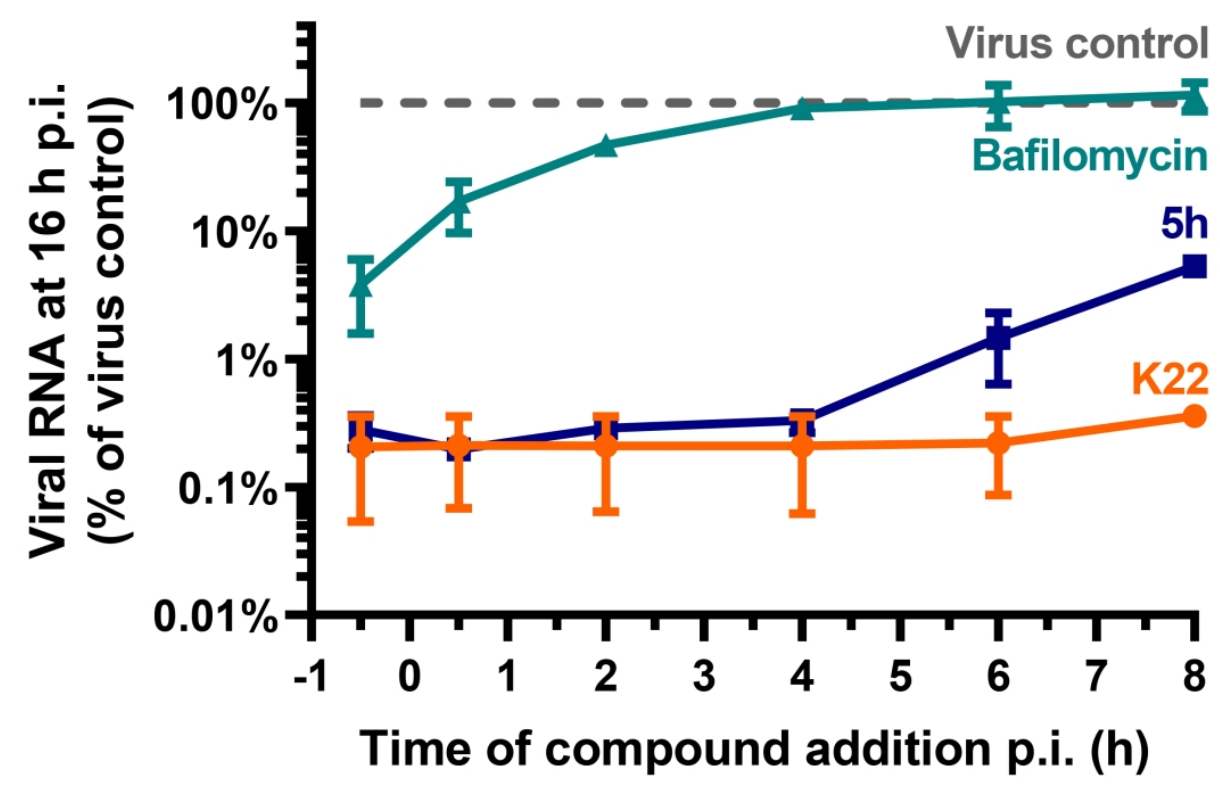

Figure 2. 5h acts post-entry at an early stage in viral RNA synthesis. Compound addition was delayed until different time points after infecting HEL cells with HCoV-229E, and viral RNA was quantified at $16 \mathrm{~h}$ p.i. Compound concentrations: bafilomycin $6.3 \mathrm{nM}$; $5 \mathbf{h}$ and $\mathrm{K} 22: 15 \mu \mathrm{M}$. The Y-axis shows the viral RNA copy number relative to the virus control (mean \pm SEM of two independent experiments). 

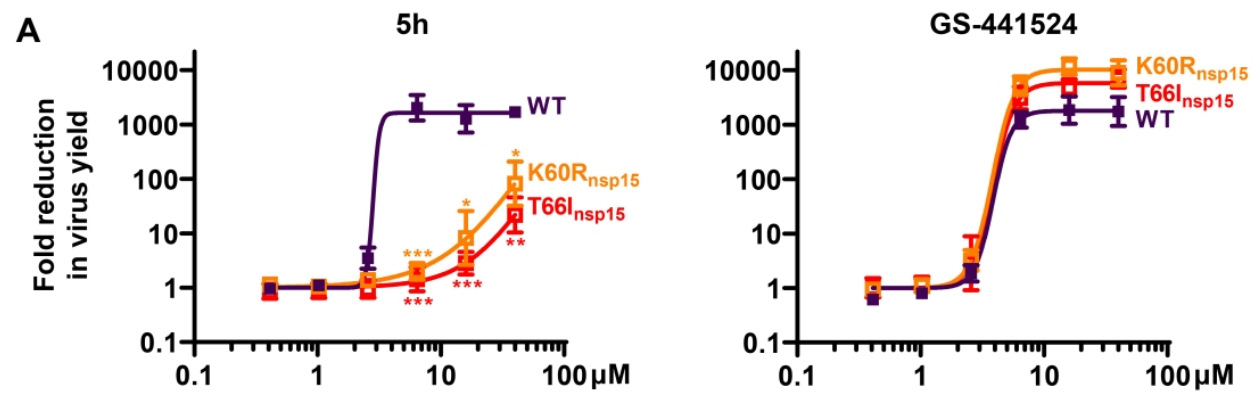

B
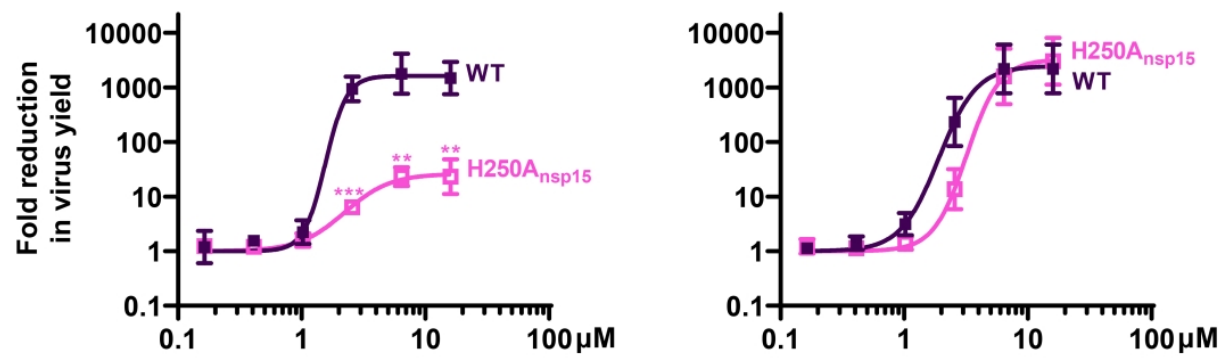

Figure 3. Mutations in nsp15 confer resistance of HCoV-229E to 5h (left panels), but not to GS-441524 (right panels). The graphs show the effect of the compounds on virus yield. (A) HEL cells infected with $\mathbf{5 h}$ resistant mutants obtained by virus passaging under $\mathbf{5 h}$ and carrying substitution K60R (first selection) or

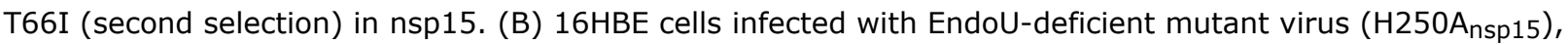
obtained by reverse genetics. ${ }^{26}$ Data points are the mean \pm SEM $(\mathrm{N}=3)$. An unpaired t-test (GraphPad Prism 8.4.3) was used to compare the mutant viruses to WT, and the resulting two-tailed $p$-values were adjusted for multiple comparisons using Holm-Sidak $(\mathrm{a}=0.05) .{ }^{*}, \mathrm{P}<0.05 ;^{* *}, \mathrm{P}<0.01 ;^{* * *}, \mathrm{P}<0.001$. 


\section{A}

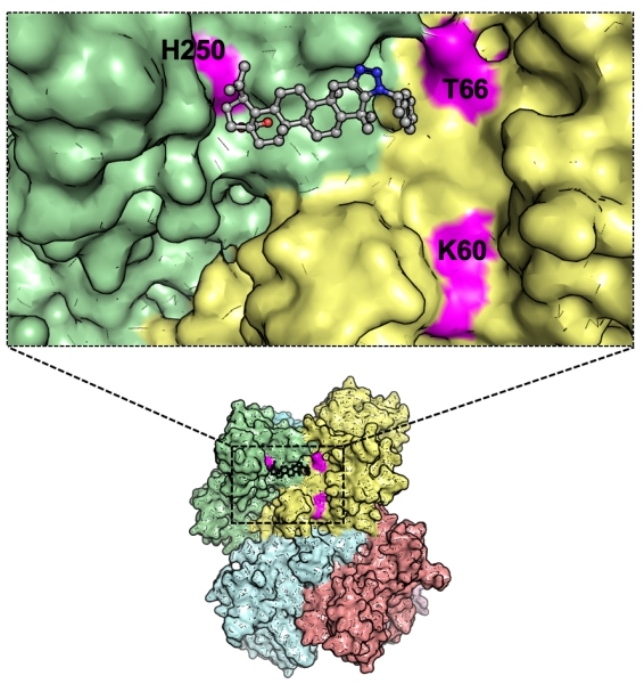

B

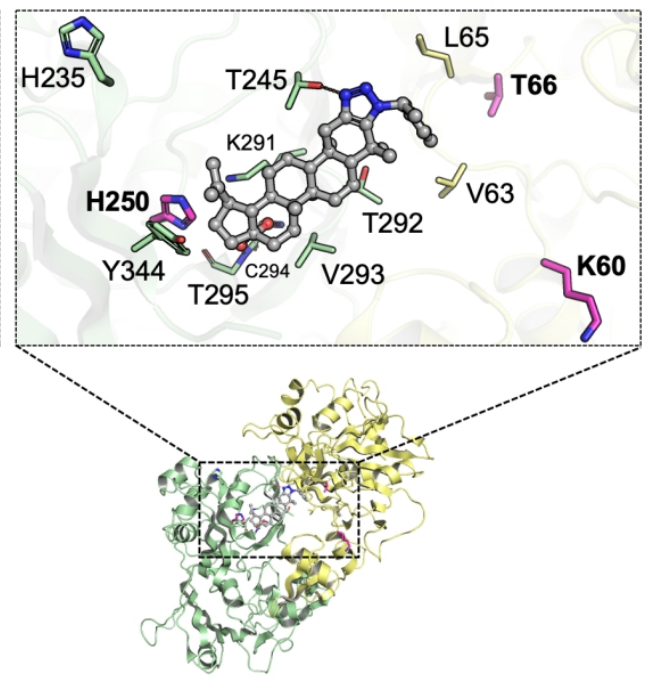

Figure 4. Binding mode of $\mathbf{5 h}$ in HCoV-229E nsp15 hexameric protein (PDB 4RS4), as predicted by docking. (A) The hydrophobic pocket lies adjacent to the EndoU catalytic centre (catalytic triad consisting of His235, His250 and Lys291) and at an nsp15 dimer interface (monomers depicted in differently colored surface). The pocket is surrounded by His250, Lys60 and Thr66, explaining why $\mathbf{5 h}$ is inactive against HCoV-229E viruses carrying mutations at these sites. (B) $\mathbf{5 h}$ occupies the pocket by making hydrophobic interactions with Val293 and side chain fragments of Lys291 and Thr292. The molecule further engages in hydrogen-bonding interactions with Cys294 and Thr295 via the carboxylic acid, and with Thr245 via the 1,2,3-triazole. Additional hydrophobic interactions with Val63, Leu65 and Thr292 are made via the aromatic ringsubstituted 1,2,3-triazole moiety. 


\section{A}

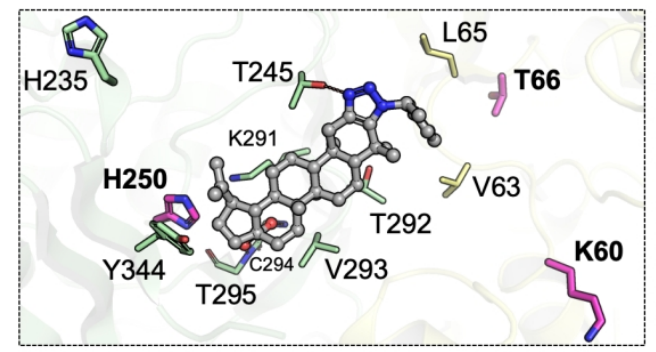

B

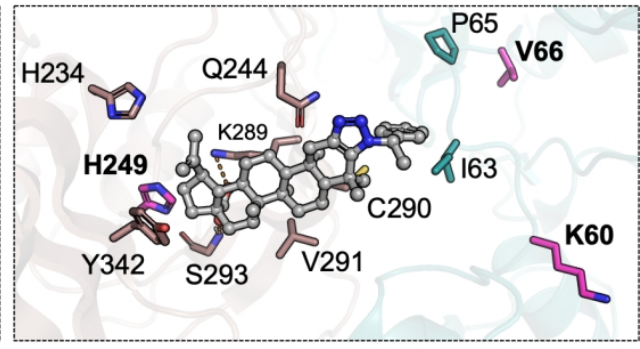

Figure 5. Comparison of the hydrophobic pocket, occupied by $\mathbf{5 h}$, in the nsp15 proteins of HCoV-229E (left; PDB 4RS4) and SARS-CoV-2 (right; PDB 7K10). The carboxylic acid of $\mathbf{5 h}$ forms hydrogen bonds with both nsp15 binding pockets. On the other hand, the 1,2,3-triazole group engages hydrogen-bonding interactions with the HCoV-229E nsp15 protein but is incompatible with the SARS-CoV-2 pocket.

$338 \times 109 \mathrm{~mm}(135 \times 135 \mathrm{DPI})$ 


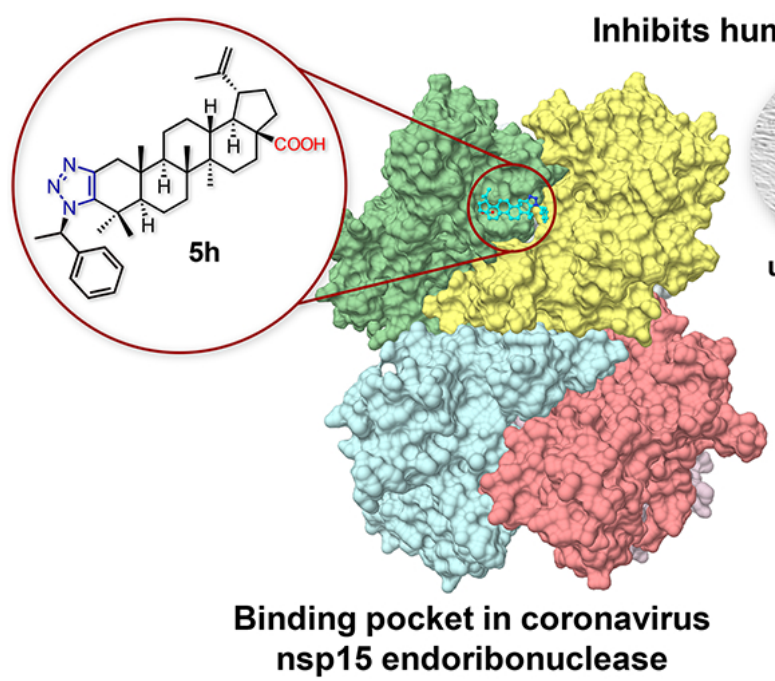

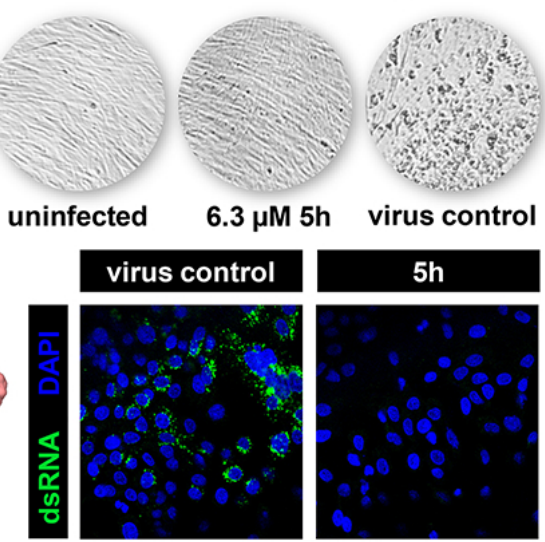

Prevents formation of viral dsRNA

TOC graphic 